July 2003 • NREL/TP-620-34599

\title{
Policies and Market Factors Driving Wind Power Development in the United States
}

L. Bird and B. Parsons

National Renewable Energy Laboratory

T. Gagliano and M. Brown

National Conference of State Legislatures

R. Wiser and M. Bolinger

Lawrence Berkeley National Laboratory
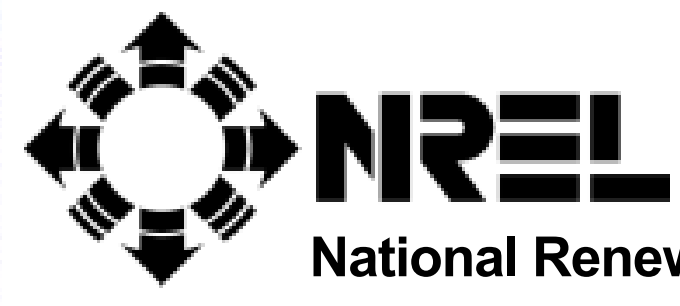

National Renewable Energy Laboratory

1617 Cole Boulevard

Golden, Colorado 80401-3393

NREL is a U.S. Department of Energy Laboratory

Operated by Midwest Research Institute $\bullet$ Battelle $\bullet$ Bechtel

Contract No. DE-AC36-99-G010337 


\section{Policies and Market Factors Driving Wind Power Development in the United States}

L. Bird and B. Parsons

National Renewable Energy Laboratory

T. Gagliano and M. Brown

National Conference of State Legislatures

R. Wiser and M. Bolinger

Lawrence Berkeley National Laboratory

Prepared under Task No. WER3.3010

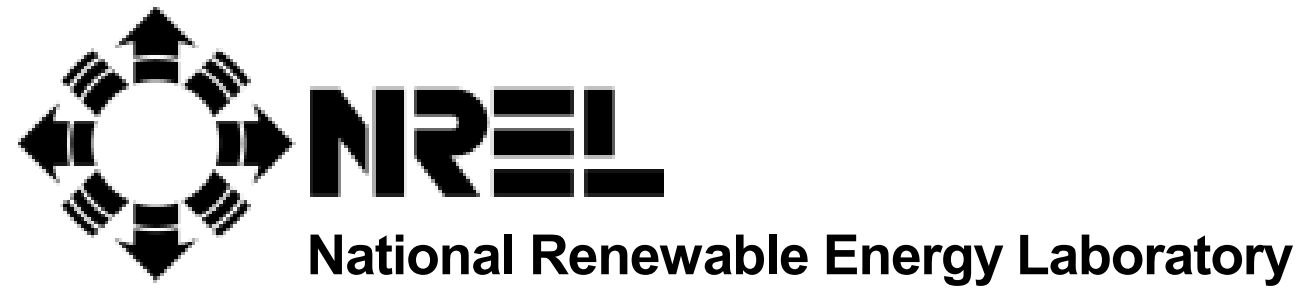

1617 Cole Boulevard

Golden, Colorado 80401-3393

NREL is a U.S. Department of Energy Laboratory

Operated by Midwest Research Institute • Battelle • Bechtel

Contract No. DE-AC36-99-G010337 


\section{NOTICE}

This report was prepared as an account of work sponsored by an agency of the United States government. Neither the United States government nor any agency thereof, nor any of their employees, makes any warranty, express or implied, or assumes any legal liability or responsibility for the accuracy, completeness, or usefulness of any information, apparatus, product, or process disclosed, or represents that its use would not infringe privately owned rights. Reference herein to any specific commercial product, process, or service by trade name, trademark, manufacturer, or otherwise does not necessarily constitute or imply its endorsement, recommendation, or favoring by the United States government or any agency thereof. The views and opinions of authors expressed herein do not necessarily state or reflect those of the United States government or any agency thereof.

Available electronically at http://www.osti.gov/bridge

Available for a processing fee to U.S. Department of Energy and its contractors, in paper, from:

U.S. Department of Energy

Office of Scientific and Technical Information

P.O. Box 62

Oak Ridge, TN 37831-0062

phone: 865.576 .8401

fax: 865.576.5728

email: reports@adonis.osti.gov

Available for sale to the public, in paper, from:

U.S. Department of Commerce

National Technical Information Service

5285 Port Royal Road

Springfield, VA 22161

phone: 800.553.6847

fax: 703.605.6900

email: orders@ntis.fedworld.gov

online ordering: http://www.ntis.gov/ordering.htm 


\section{Table of Contents}

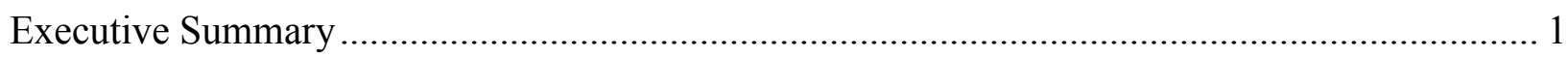

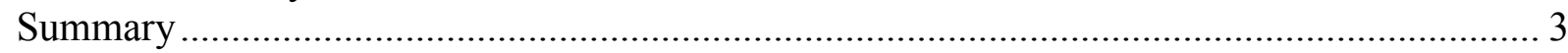

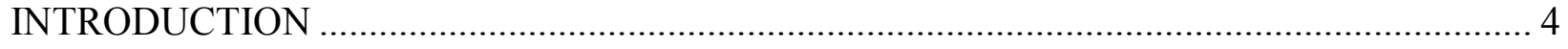

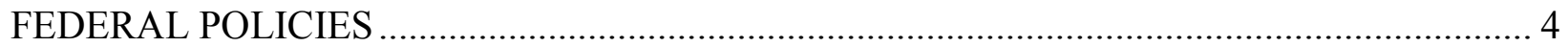

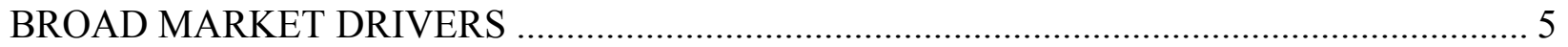

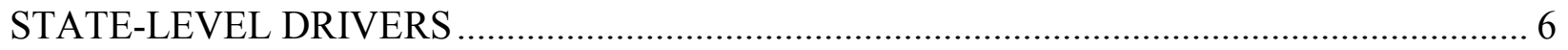

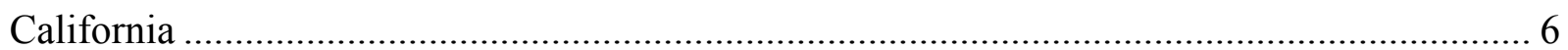

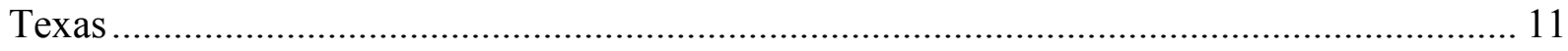

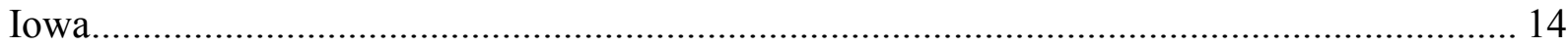

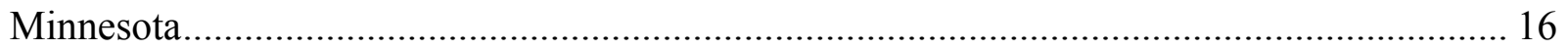

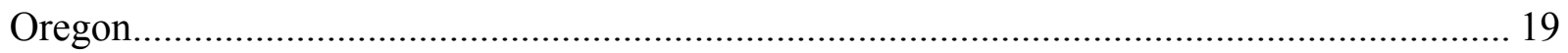

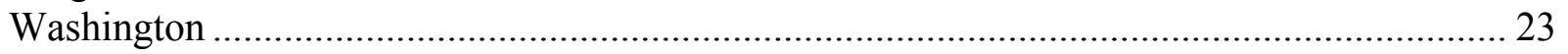

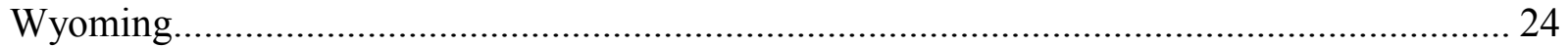

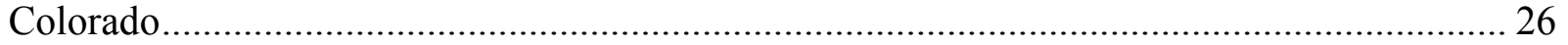

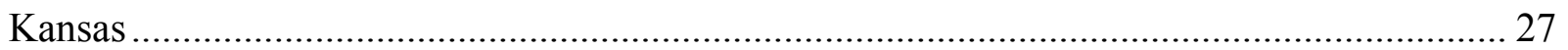

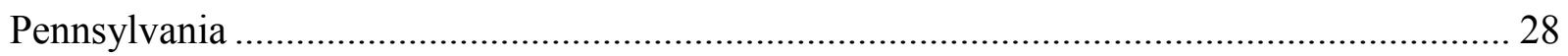

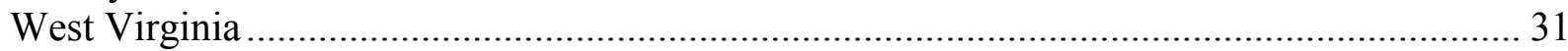

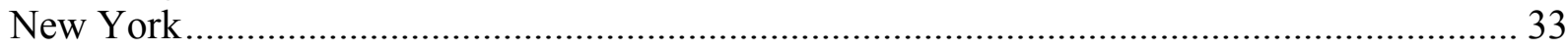

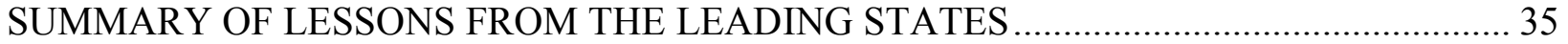

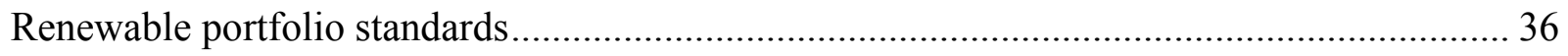

System benefits funds ..................................................................................................... 37

Integrated Resource Planning (IRP)/Settlement Agreements................................................. 37

Property tax incentives ............................................................................................... 38

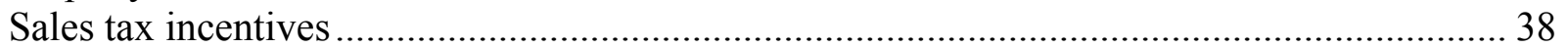

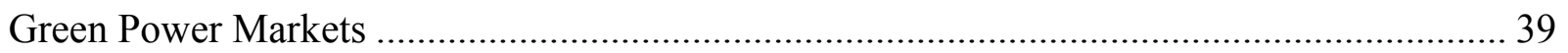

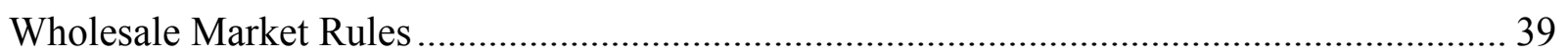

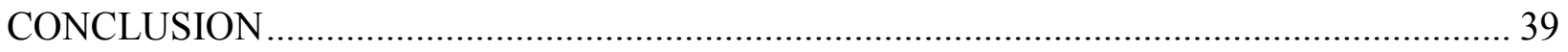

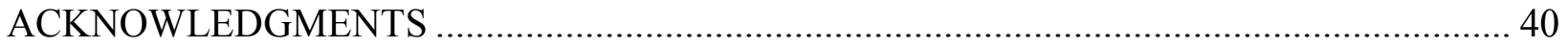




\section{List of Tables}

TABLE 1: COMPARISON OF STATE WIND CAPACITY, RESOURCE POTENTIAL, AND INCENTIVES.

TABLE 2: CUMULATIVE WIND ENERGY CAPACITY BY STATE, 1998-2002 (MEGAWATTS)

TABLE 3: TEXAS INSTALLED WIND ENERGY CAPACITY ......................................................................

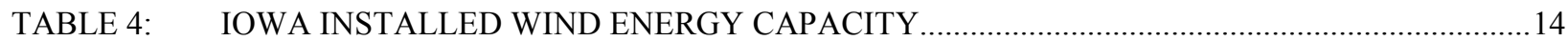

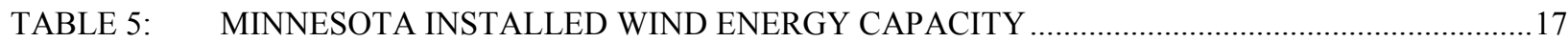

TABLE 6: OREGON INSTALLED WIND ENERGY CAPACITY ………....................................................

TABLE 7: WASHINGTON INSTALLED WIND ENERGY CAPACITY ……………….............................23

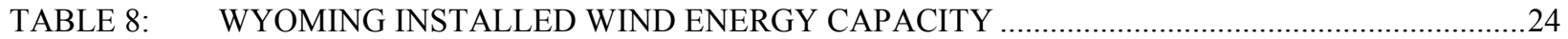

TABLE 9: COLORADO INSTALLED WIND ENERGY CAPACITY ……..............................................2

TABLE 10: PENNSYLVANIA INSTALLED WIND ENERGY CAPACITY ...................................................29

TABLE 11: NEW YORK INSTALLED WIND ENERGY CAPACITY …………...........................................33

TABLE 12: COMPARISON OF STATE WIND CAPACITY, RESOURCE POTENTIAL, AND

INCENTIVES

\section{List of Figures}

FIGURE 1: CUMULATIVE U.S. WIND ENERGY CAPACITY ....................................................................

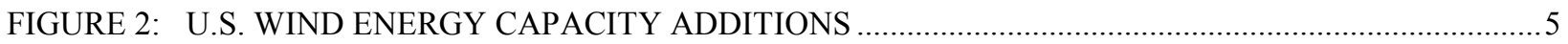

FIGURE 3: CALIFORNIA WIND ENERGY GENERATION, 1983-2001 …................................................. 


\section{Executive Summary}

In the United States, there has been substantial recent growth in wind energy generating capacity, with growth averaging $24 \%$ annually during the past five years. With this growth, an increasing number of states are experiencing investment in wind energy. Wind installations currently exist in about half of all U.S. states. This paper explores the policies and market factors that have been driving utility-scale wind energy development in the United States, particularly in the states that have achieved a substantial amount of wind energy investment in recent years. Although there are federal policies and overarching market issues that are encouraging investment nationally, much of the recent activity has resulted from state-level policies or localized market drivers. In this paper, we identify the key policies, incentives, regulations, and markets affecting development, and draw lessons from the experience of leading states that may be transferable to other states or regions. We provide detailed discussions of the drivers for wind development in a dozen leading states - California, Colorado, Iowa, Kansas, Minnesota, New York, Oregon, Pennsylvania, Texas, Washington, West Virginia, and Wyoming.

Two fundamental messages resulting from this research are:

1) State tax and financial incentives, as well as state renewable portfolio standards (RPS), can and do have an important effect on wind energy development. This impact is most pronounced when wind generation is already nearly competitive with more traditional generation resources (e.g., gas-fired generation).

2) The increasingly lower cost of wind generated electricity - due in part to a movement toward larger, more efficient turbines, and facilitated by federal tax incentives - is now an important driver for new wind installations. Simply said, there are some regions of the United States in which wind power is the lower-cost resource option.

Any state policy or incentive functions in the context of other powerful drivers, such as: the quality of the wind resource, the cost of conventional generation, the need for new electricity supplies, the willingness of power companies to integrate wind into their systems, the ease of siting and permitting wind facilities, the quality of the power delivery system, and the rules that govern the transmission system.

State drivers also function within the context of current federal policies incentives, which have played an important role in encouraging recent wind power development. The most notable and effective of these is the federal production tax credit (PTC), which provides a $1.8 \phi / \mathrm{kWh}$ credit for the entire output of a facility during the first 10 years of its operation. The PTC has lowered the cost of wind energy and is a key policy that works in conjunction with other state or local drivers. Other important federal policies include five-year accelerated depreciation and to a lesser extent the Renewable Energy Production Incentive (REPI). The REPI provides a production incentive to wind projects owned by publicly owned utilities and cooperatives that do not have federal tax liabilities, but is subject to annual Congressional appropriations.

Within the context of these broader market drivers and federal policies, state policies and markets have in many cases have been instrumental in stimulating wind energy development. Table 1 provides a summary and comparison of installed capacity, resource potential, and policy incentives in the states examined in this paper. Based on the experience of these states, the following policies and market factors have been identified as key drivers of wind energy development at the state level. 
Renewable portfolio standards - RPS policies or purchase mandates are the most powerful tool that a state can use to promote wind energy. So far, these have been particularly important for driving wind energy investment in Texas, Minnesota, and Iowa, where more than 1,700 MW of new capacity has been developed to meet the requirements of just these three states. In addition, some portfolio standards, such as those in Wisconsin and New Jersey, have been directly responsible for wind development, not only within the state, but also in neighboring states. In the future, state RPS policies, such as those under development in California and New York, are expected to play a leading role in stimulating wind energy development. However, not all RPS policies are equally effective; details in design and implementation make a difference.

TABLE 1: COMPARISON OF STATE WIND CAPACITY, RESOURCE POTENTIAL, AND INCENTIVES

\begin{tabular}{|c|c|c|c|c|c|c|c|}
\hline & State & $\begin{array}{l}\text { Cumulative } \\
\text { Installed } \\
\text { Capacity } \\
2002 \text { (MW) }\end{array}$ & $\begin{array}{l}\text { Cumulative } \\
\text { Installed } \\
\text { Capacity } \\
1998(\mathrm{MW}) \\
\end{array}$ & $\begin{array}{l}\text { Resource } \\
\text { Rank }^{1}\end{array}$ & $\begin{array}{l}\text { RPS/ } \\
\text { Mandate }\end{array}$ & $\begin{array}{l}\text { Retail } \\
\text { Green } \\
\text { Power } \\
\text { Products } \\
\end{array}$ & Financial Incentives \\
\hline 1 & $\mathrm{CA}$ & 1822 & 1395 & 17 & $20 \%$ by 2017 & $6 * *$ & System benefits charge (SBC) \\
\hline 2 & TX & 1096 & 41 & 2 & $\begin{array}{l}2000 \mathrm{MW} \text { by } \\
2009\end{array}$ & $4 * *$ & $\begin{array}{l}\text { Property tax, franchise tax } \\
\text { exemption }\end{array}$ \\
\hline 3 & IA & 423 & 5 & 10 & 105 aMW & 8 & Property tax, sales tax, loan fund \\
\hline 4 & $\mathrm{MN}$ & 336 & 135 & 9 & $\begin{array}{l}425 \text { MW by } \\
2002,400 \\
\text { MW by } 2012 ; \\
10 \% \text { by } 2015 \\
\text { goal }\end{array}$ & 63 & $\begin{array}{l}\text { Fund, property tax, production } \\
\text { incentive, accelerated } \\
\text { depreciation }\end{array}$ \\
\hline 5 & WA & 228 & 0 & $>20$ & -- & $14 * *$ & Corporate tax, sales tax incentive \\
\hline 6 & OR & 218 & 25 & $>20$ & -- & $10 * *$ & $\begin{array}{l}\text { SBC, business tax credit, } \\
\text { property tax exemption }\end{array}$ \\
\hline 7 & WY & 141 & 1 & 7 & -- & $2 * *$ & -- \\
\hline 8 & $\mathrm{KS}$ & 114 & 0 & 3 & -- & $* *$ & Property tax exemption \\
\hline 9 & WV & 66 & 0 & $>20$ & -- & $* *$ & \\
\hline 10 & $\mathrm{CO}$ & 61 & 0 & 11 & -- & $20 * *$ & \\
\hline 11 & NY & 49 & 0 & 15 & $\begin{array}{l}25 \% \text { by } 2013 \\
\text { planned }\end{array}$ & & $\mathrm{SBC}$ \\
\hline 12 & PA & 35 & 0 & $>20$ & & & $\mathrm{SBC}$ \\
\hline & Total & 4589 & 1602 & & & & \\
\hline
\end{tabular}

System benefits funds - System benefits funds can also promote wind energy development. These funds have proven to be important for stimulating investment in wind energy facilities in states such as Pennsylvania, New York, and California, and may become increasingly important in places like Oregon. Relative to some other types of policies, system benefits funds offer the advantage of flexibility; they can be used to provide a variety of financial incentives such as debt or equity financing, production incentives, grants, or support for the development of green markets. In some cases, system benefits funds can be helpful in states with little experience in wind development by funding activities such as wind-resource mapping and site preparation.

Integrated Resource Planning (IRP)/Settlement Agreements - The IRP process and settlement agreements have driven wind power development in some regions. For example, IRP has been important in Colorado, where the utility commission required the construction of nearly $200 \mathrm{MW}$ of new wind facilities found to be cost-effective as a result of increases in natural gas prices. In Oregon, one utility issued an IRP plan that calls for 1,400 MW of new wind projects to meet projected load growth. Merger settlement agreements also have presented limited opportunities for wind development, particularly in the Pacific Northwest and the Northeast. 
Sales tax incentives - Sales tax abatements can be important to wind developers because of the capital-intensive nature of wind energy facilities. Again, however, they may not be able to stimulate new wind energy investments by themselves. Sales tax exemptions are a one-time tax benefit that developers realize at the time of equipment purchase. In a state with very good to excellent wind resources and good transmission availability, sales tax abatements may influence a developer's decision to build a wind facility. One concern regarding the use of sales tax exemptions is that they reduce potential state tax revenues, which can pose problems for states during tight economic conditions.

Green Power Markets - Green markets can provide an important revenue stream to support investment in wind energy facilities. Consumer demand for green power has been a key contributor to the successful development of projects in several Mid-Atlantic states, Colorado, Wyoming, and in the Pacific Northwest, among others. In some instances, such as Colorado and Pennsylvania, green markets have provided utilities, regulators, and advocates the opportunity to gain experience with wind resources, paving the way for further development. Although green markets may not alone provide enough stable revenue to support large-scale development, they can be used in conjunction with other policy mechanisms. Where RPS policies are in place, green power marketing can enable developers to construct larger and more cost-effective projects, with a portion being used to meet the RPS and a portion to meet consumer demand.

Wholesale Market Rule-Wholesale market rules that accommodate intermittent generators can also influence wind energy development in a state or in a region. Markets that are fluid and provide real-time scheduling, capacity credit for wind, and allow schedule deviations without penalties can help facilitate wind energy development.

\section{Summary}

It is impossible to discern one single driver for wind development; all of the different drivers function as a package and influence one another's effectiveness. It is clear from the tremendous growth in wind development that a combination of policies, vastly improved economics, and a developing market for green power are all having a sizable effect on the wind industry. Of the various state policy drivers, the renewable portfolio standard appears to be the most effective. But a variety of financial incentives can also wield a great deal of influence. Any state policy must, however, operate in the general context of the wind resource, transmission constraints, and market rules, which ultimately may limit any new investment in wind. 


\section{INTRODUCTION}

Wind energy development in the United States has accelerated in recent times, with an average annual growth rate of $24 \%$ during the past five years. By the end of 2002, total installations reached 4,685 MW (see Figure 1), which placed the United States third in wind power capacity globally, following Germany and Spain (which reported 12,000 MW and 4,830 MW, respectively). According to the American Wind Energy Association (AWEA), growth in the U.S. wind industry is expected to continue in the near term, with another 1,100 to $1,400 \mathrm{MW}$ projected to come on-line in 2003. ${ }^{1}$ With this growth, an increasing number of states are experiencing investment in wind energy projects. Current installations are spread among 26 states, although the vast majority of capacity is concentrated in about half of those states.

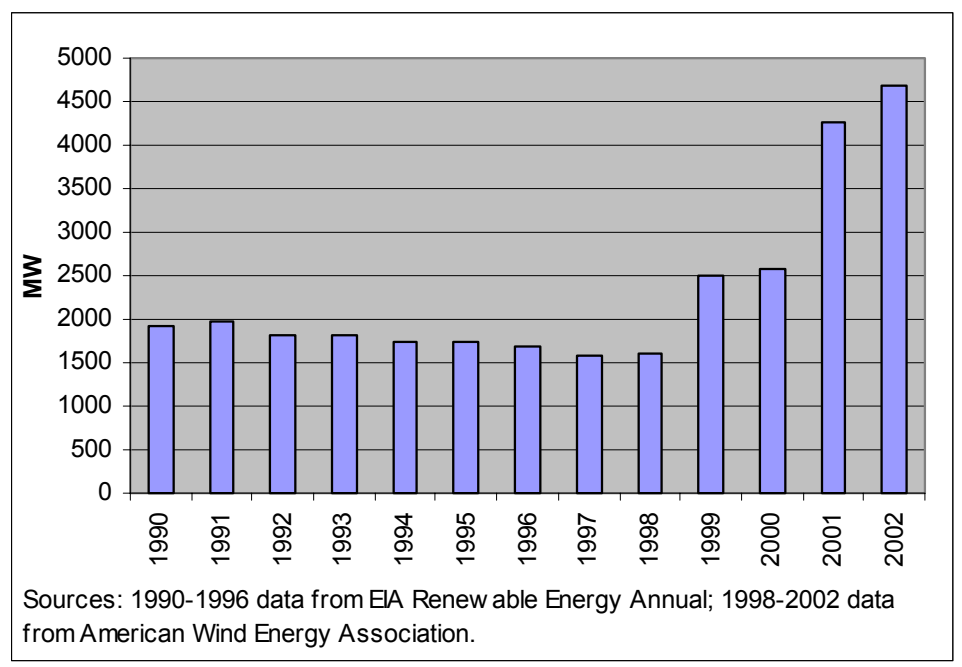

FIGURE 1: CUMULATIVE U.S. WIND ENERGY CAPACITY

This paper explores the policies and market factors that have been driving wind energy development in the United States, particularly in the states that have achieved a substantial amount of wind energy investment in recent years. Although there are federal policies and overarching market issues that are encouraging investment nationally, much of the recent activity has resulted from state-level policies or localized market drivers. In this paper, we identify the key policies, incentives, regulations, and markets affecting development, and draw lessons from the experience of leading states that may be transferable to other states or regions. We first look briefly at the federal policies and broad market issues, and then focus more narrowly on statespecific experience. We provide detailed discussions of the drivers for wind development in a dozen leading states - California, Colorado, Iowa, Kansas, Minnesota, New York, Oregon, Pennsylvania, Texas, Washington, West Virginia, and Wyoming. Finally, we conclude with a discussion of the key lessons for policy-makers, regulators, advocates, and other stakeholders.

\section{FEDERAL POLICIES}

Federal tax and financial incentives have played an important role in encouraging wind power development. The most notable and effective of these incentives is the federal production tax credit (PTC), which is an inflation-adjusted credit of $1.8 \notin / \mathrm{kWh}$ for the entire output of a facility during the first 10 years of its operation. Originally created under the 1992 Energy Policy Act, the PTC was initially available for projects installed between 1994 and June 30, 1999. The PTC was subsequently extended to December 2001 and then again to December 2003, which is when it will expire unless Congress takes further action. The impact of the PTC on the wind energy industry is evident in the boom-bust cycle of development in recent years. Wind energy installations have peaked in years when the PTC was scheduled to expire as developers have

\footnotetext{
${ }^{1}$ AWEA, "U.S. Wind Industry on Track to Grow More than 25\% in 2003," May 8, 2003 http://www.awea.org/news/news030508gro.html. "Record Growth For Global Wind Power In 2002," March 3 , 2003. http://www.awea.org/news/news030303gbl.html
} 
rushed to complete projects in time to take advantage of the incentives. In the off years, development has lagged because of the uncertainty surrounding the PTC extension and the leadtime necessary to plan and complete projects. (see Figure 2)

The Renewable Energy Production Incentive (REPI) was also created under the 1992 Energy Policy Act. The REPI provides a $1.8 \notin / \mathrm{kWh}$ inflation-adjusted cash production incentive to wind (and other renewable energy) projects owned by publicly owned utilities and cooperatives that do not have federal tax liabilities, and therefore are unable to take advantage of the PTC. However, funding for the REPI is subject to Congressional appropriations each year, so there is

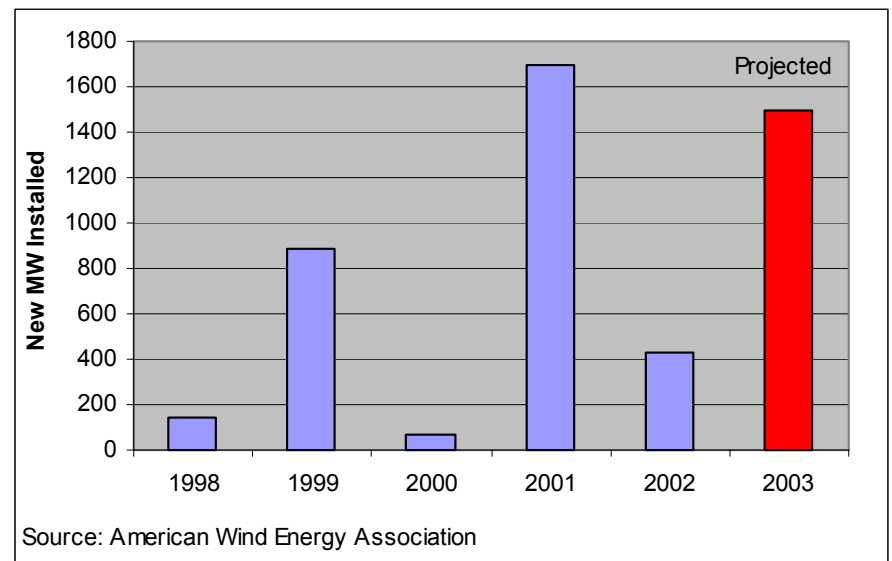

FIGURE 2: U.S. WIND ENERGY CAPACITY ADDITIONS significant uncertainty regarding the annual availability of the incentive. This has limited its effectiveness as a driver of wind power development because eligible public utilities cannot rely on this revenue stream when financing projects.

Other federal policy incentives that contributed primarily to the early development of the wind energy industry, particularly in California, have included the Public Utility Regulatory Policies Act (PURPA), investment tax credits, and accelerated depreciation. Of these, the five-year accelerated depreciation schedule for wind energy investments is still available and most relevant today. The Job Creation and Worker Assistance Act of 2002 expanded depreciation incentives by allowing wind project owners to take an additional 30\% depreciation in the first year for assets purchased after September 10, 2001, and before September 11, 2004, and placed in service by January 1, 2005.

\section{BROAD MARKET DRIVERS}

Recently, market forces have also played a role in increasing the cost-effectiveness of wind generation. During the past several years, natural gas prices have experienced unprecedented volatility, which has driven up the cost of electricity generated from natural gas-fired generators and helped close the gap between the cost of wind energy and conventional sources. During the 1990's, prices for natural gas averaged about \$2 per thousand cubic feet (Mcf) at the wellhead and varied by about $35 \%$ during seasonal peaks. Then in the winter of 2000/2001, wellhead prices reached a new peak of more than $\$ 8 / \mathrm{Mcf}$ and climbed even higher during the winter of 2002/2003. In good wind regimes, wind energy generation has been shown to be cost-effective with natural gas at prices of $\$ 3.50 / \mathrm{Mcf}$.

Wind energy generation costs have also dropped with the movement toward larger, more efficient turbines. These larger turbines have improved efficiencies by as much as 15 to 20 percent. Further, high wholesale electricity prices - resulting not only from high natural gas prices but also from supply-demand imbalances associated with the Western energy crisis-have improved the relative competitiveness of wind energy generation. 
With the recent downturn in the U.S. economy, growth in the wind industry has been tempered to some degree. Access to capital has become restricted because many energy companies are already burdened with excessive amounts of debt and have sub-par credit ratings. The slowdown in the economy has also reduced demand for electricity, causing many developers to shelve plans for new power plants of all types. On the other hand, low interest rates have prevailed in the sluggish economy, reducing the cost of financing for projects that are able to obtain it. Despite the challenges of current market conditions, AWEA projects that another 1,100 MW to 1,400 MW of new wind energy capacity will be installed in the United States by the end of 2003.

\section{STATE-LEVEL DRIVERS}

Wind energy development has historically been concentrated in California and, to a lesser extent, in a few other states. More recent development, however, has spread among a broader crosssection of the country. The key factors that have been driving development in new states include renewable portfolio standards (RPS) and other forms of renewable energy mandates, state tax and financial incentives, consumer demand for green power, the improving economics of wind generation, and market rules that are favorable to wind. In the following sections, we examine the drivers of increased wind energy investment in the 12 states listed in Table 2, which collectively represent $98 \%$ of the installed capacity in the United States.

TABLE 2: CUMULATIVE WIND ENERGY CAPACITY BY STATE, 1998-2002 (MEGAWATTS)

\begin{tabular}{|l|l|l|l|l|l|c|}
\hline State & $\mathbf{1 9 9 8}$ & $\mathbf{1 9 9 9}$ & $\mathbf{2 0 0 0}$ & $\mathbf{2 0 0 1}$ & $\mathbf{2 0 0 2}$ & \% of Total \\
\hline California & 1395 & 1646 & 1646 & 1714 & 1822 & $39 \%$ \\
\hline Texas & 41 & 180 & 180 & 1096 & 1096 & $23 \%$ \\
\hline Iowa & 5 & 243 & 243 & 324 & 423 & $9 \%$ \\
\hline Minnesota & 135 & 272 & 290 & 319 & 336 & $7 \%$ \\
\hline Washington & 0 & 0 & 0 & 178 & 228 & $5 \%$ \\
\hline Oregon & 25 & 25 & 25 & 158 & 218 & $5 \%$ \\
\hline Wyoming & 1 & 73 & 91 & 141 & 141 & $3 \%$ \\
\hline Kansas & 0 & 2 & 2 & 114 & 114 & $2 \%$ \\
\hline West Virginia & 0 & 0 & 0 & 0 & 66 & $1 \%$ \\
\hline Colorado & 0 & 22 & 22 & 61 & 49 & $1 \%$ \\
\hline New York & 0 & 0 & 18 & 49 & 35 & $1 \%$ \\
\hline Pennsylvania & 0 & 0 & 11 & $\mathbf{4 5 8 9}$ & $\mathbf{4 6 8 5}$ & $\mathbf{9 8 \%}$ \\
\hline Total 12 States & $\mathbf{1 6 0 2}$ & $\mathbf{2 4 6 3}$ & $\mathbf{2 5 2 8}$ & $\mathbf{4 1 8 9}$ & $\mathbf{1 0 0 \%}$ \\
\hline Total 50 States & $\mathbf{1 6 1 6}$ & $\mathbf{2 5 0 0}$ & $\mathbf{2 5 6 6}$ & $\mathbf{4 2 6 1}$ & \\
\hline $\begin{array}{l}\text { Source: American Wind Energy Association (AWEA) wind project database } \\
\text { http://www.awea.org/projects/index.html }\end{array}$
\end{tabular}

\section{California}

California has been the historic leader in wind energy development, both in the United States and internationally. Wind energy investment began in earnest in the early 1980 s and the industry grew substantially during the decade, resulting in a total installed capacity of about 1,880 MW by 1990. Although development slowed greatly in the 1990s and some projects ceased operation, California still has the most wind energy capacity, with 1,822 MW installed as of the end of 2002. Initially, California's wind energy industry emerged as a result of state and federal tax incentives and the 1978 Public Utility Regulatory Policies Act (PURPA), combined with strong implementation of PURPA by the state's public utility commission. More recently, new and existing projects have been supported by production incentives and other financial incentives funded through a systems benefits charge on electricity sales created under California's electric industry restructuring law. It is expected that the newly created renewables portfolio standard 
and the continuing availability of systems benefits funds will be the primary drivers of future growth. ${ }^{2}$ These policies and incentives are discussed in turn below.

\section{PURPA and State Tax Incentives}

During the 1980s, federal and state tax incentives and PURPA were primarily responsible for encouraging widespread development of California's wind energy resources. At the federal level, the 1978 Energy Tax Act created a business investment tax credit for wind and other renewable energy sources that entitled investors to receive income tax credits of up to $25 \%$ of the cost of the technology. The credit expired for wind energy systems in December 1985. In addition, the 1981 Economic Recovery Tax Act allowed five-year accelerated depreciation of capital for wind energy and other renewable energy equipment. In conjunction with these federal incentives, California instituted a $25 \%$ investment tax credit for wind energy systems from about 1980 through 1983. When combined with the federal incentive, this resulted in an effective tax credit of nearly $50 \%$. As a result, the state's wind capacity grew from $176 \mathrm{MW}$ in 1982 to 1,015 MW in $1985 .^{3}$

The implementation of PURPA by the California Public Utilities Commission (CPUC) also spurred tremendous investment in wind energy. Under PURPA, utilities are required to purchase the output of qualifying facilities at the utility's avoided cost as defined and implemented by states. $^{4}$ In California, the CPUC showed strong support for PURPA and approved long-term contracts for renewable generators at very high prices (based on today's standards) because the avoided cost calculations were based on forecasted short-run costs of oil and natural gas. At the time, oil and natural gas prices were expected to rise to higher levels than they actually reached in subsequent years. ${ }^{5}$ Starting in about 1983, the most commonly granted contracts for independent renewable energy generators were Standard Offer \#4 contracts, which included capacity payments for 20 to 30 years and fixed-priced energy payments for 10 years that ranged from about $5 \notin / \mathrm{kWh}$ to more than $12 \notin / \mathrm{kWh}^{6}{ }^{6}$ As of 1995 , EIA estimated that California utilities paid an average of $12.79 \phi / \mathrm{kWh}$ for renewable energy from qualifying facilities under PURPA contracts. ${ }^{7}$

By 1985, there were more than 15,000 MW of qualifying facilities under contract, not all of which were subsequently built. The Standard Offer \#4 contracts became so popular, in fact, that the CPUC became concerned about the number of planned projects and suspended the contract in April $1985 .^{8}$ Nevertheless, the wind energy industry continued to grow for a number of years, reaching a peak of 1940 MW of installed capacity in 1991, all of which was owned by nonutility

\footnotetext{
${ }^{2}$ California has adopted a number of policies to support small-scale wind turbines for farm or residential applications, which are discussed in more detail in Forsythe, T., M. Pedden, and T. Gagliano; The Effects of Net Metering on the Use of Small Scale Wind Systems in the United States, National Renewable Energy Laboratory, NREL/TP-500-32471, November 2002.

${ }^{3}$ Gielecki, M., F. Mayes, and L. Prete; "Incentives, Mandates, and Government Programs for Promoting Renewable Energy" in Renewable Energy Issues and Trends 2000, Energy Information Administration, DOE/EIA-0628 (2000), February 2001.

${ }^{4}$ Qualifying facilities included electric-generating resources rated at less than $80 \mathrm{MW}$, with at least $75 \%$ of the energy input from renewable sources.

5 Guey-Lee, L., "Renewable Electricity Purchases: History and Recent Developments," Renewable Energy 1998 :

Issues and Trends, U.S. DOE Energy Information Administration (EIA). 1999

http://www.eia.doe.gov/cneaf/solar.renewables/rea issues/renewelec art.pdf

${ }^{6}$ Blumstein, C., L.S. Friedman, and R.J. Green; The History of Restructuring in California, University of California Energy Institute, Berkeley, CSEM WP 103, August 2002.

${ }^{7}$ Guey-Lee 1999.

${ }^{8}$ Blumstein, et al. 2002.
} 
generators, according to the U.S. Department of Energy (DOE). ${ }^{9}$ However, the mid-1990s marked a period of decline as the long-term PURPA contracts began to expire and some wind projects ceased operating. (see Figure 3$)^{10}$

\section{Electric Restructuring and System Benefits Funds}

With the advent of electric market restructuring, a new round of policy incentives became available to revive the state's wind industry. California's 1996 restructuring legislation $(\mathrm{AB}$ 1890) established a system benefits charge on all electricity sold by the state's investor-owned utilities to support renewable energy and energy efficiency. The charge generated approximately $\$ 540$ million in funding for existing, new,

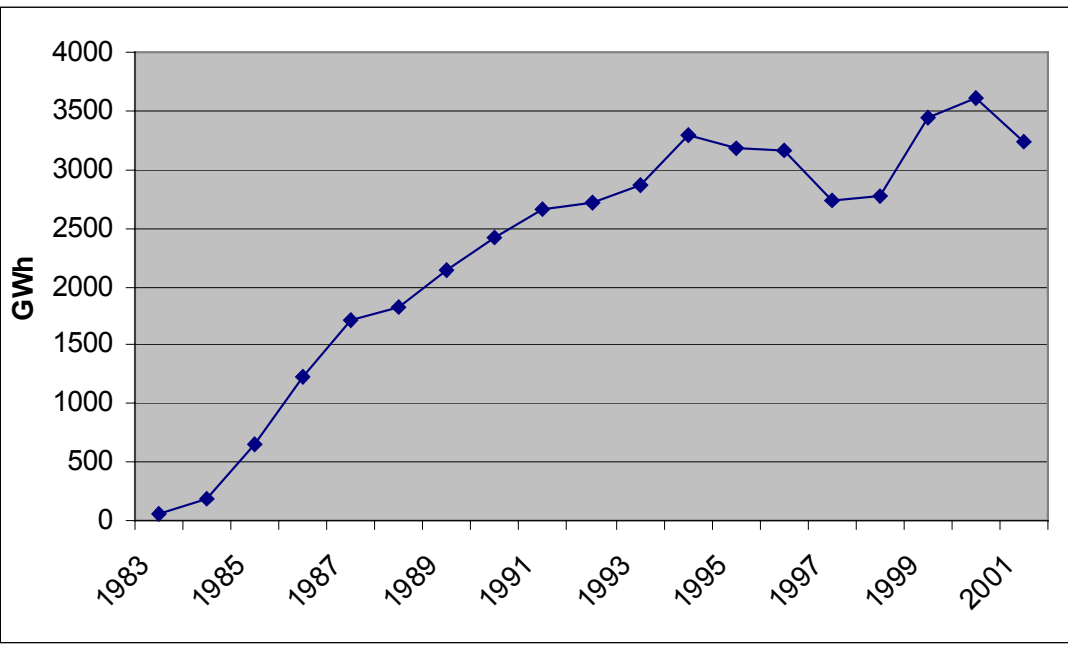

FIGURE 3: CALIFORNIA WIND ENERGY GENERATION, 1983-2001 and emerging in-state renewable energy sources during the four-year transition to competition starting in 1998. Of the total funds available, 45\% (\$243 million) was allocated for existing renewables, 30\% (\$162 million) for new renewables, and another 14\% (\$75.6 million) for reducing the cost of green power for end-use customers. The remainder was for small system (mostly PV) buy-downs and consumer education. ${ }^{11}$ The funds for existing and new renewables have had the greatest impact on preserving and developing utility-scale wind projects in California.

Of the funds allocated for existing renewables, $\$ 70$ million was dedicated to supporting wind resources, which were considered to be second-tier resources in terms of their need for subsidies. ${ }^{12}$ Wind projects were eligible to receive production incentives of up to $1 \notin / \mathrm{kWh}$, based on the availability of funds. As of June 2002, 275 renewable energy projects with a combined capacity of 4,500 MW were selected for incentive payments, ${ }^{13}$ including about 1,130 MW of wind projects. The wind projects received incentives totaling about $\$ 31.1$ million between July 1998 and June 2002. ${ }^{14}$ During the electricity crisis, some monies allocated for existing renewables were transferred to other accounts because electricity prices rose so high that existing generators did not need incentive payments.

\footnotetext{
${ }^{9}$ EIA, 1999 Renewable Energy Annual, Washington, D.C., DOE/EIA-0603 (99), March 2000. http://tonto.eia.doe.gov/FTPROOT/renewables/060399.pdf

${ }^{10}$ California Energy Commission, California Electrical Energy Generation: 1983 to 2001, July 2002. http://www.energy.ca.gov/electricity/ELECTRICITY_GEN_1983-2001.XLS

${ }^{11}$ California Energy Commission, Renewable Energy Program: Quarterly Report to the Legislature, July 2002 through September 2002, Publication No. 500-00-007v11, October 2002. http://www.energy.ca.gov/reports/200210-21 500-00-007V11.PDF

12 Tier 1 resources were eligible to receive the largest subsidies and included biomass, solar/thermal, and waste tire. Tier 3 resources included geothermal, digester and landfill gas, small hydro, and municipal solid waste.

${ }^{13}$ Bolinger, M., R. Wiser, L. Milford, M. Stoddard, and K. Porter. Clean Energy Funds: An Overview of State Support for Renewable Energy, Lawrence Berkeley National Laboratory, LBNL-47705, April 2001.

${ }^{14}$ California Energy Commission, Renewable Energy Program: Annual Project Activity Report to the Legislature, (\#500-02-068), December 2002, http://www.energy.ca.gov/reports/2003-01-13 500-02-068.PDF
} 
To stimulate new development, the new renewables account offered a five-year fixed production incentive capped at $1.5 \phi / \mathrm{kWh}$ for projects that became operational after September 1996. The CEC held three auctions, including a large auction in the summer of 1998 and smaller auctions in the fall of 2000 and summer of 2001, to distribute the \$241 million in available funding. The winning renewable energy projects totaled 1,300 MW, including $986 \mathrm{MW}$ of wind projects. ${ }^{15}$ The average incentive payments for the wind projects (weighted for capacity) were $1.04 \phi / \mathrm{kWh}$, $0.54 \notin / \mathrm{kWh}$, and $0.72 \notin / \mathrm{kWh}$, for each of the three auctions, respectively. ${ }^{16}$ Relatively few of these projects have come on-line, however, due in large part to their inability to secure long-term power purchase agreements, a preexisting condition that was difficult to meet because of a lack of credit worthiness among utilities resulting from the state's electricity crisis of 2000 and 2001. As of December 2002, only $138 \mathrm{MW}$ of the winning wind projects were operational. It is unclear when the rest of the wind capacity will come on-line, or what incentive level it will receive. When the state passed an RPS in the fall of 2002, it required that funds from the new renewables account be used to provide "supplemental energy payments" to buy down the above-market costs of the RPS, as discussed below.

Incentives were also available for customers who purchased renewable energy for their electricity needs, which stimulated a small amount of new wind energy development. The customer credits, which were initially set at $1.5 \phi / \mathrm{kWh}$, subsequently lowered, and recently rescinded, were initially effective in stimulating demand for green power. At one point, more than 150,000 customers in California purchased certified green power products. ${ }^{17}$ However, the market for green power was stalled in 2001 when the legislature suspended retail competition and prevented customers from switching suppliers. Up until then, the market for green power had only a small impact on wind energy development because most green power products contained only a small fraction of wind power. Nevertheless, two wind projects totaling about $19 \mathrm{MW}$ came on-line to meet consumer demand, including a 16.5-MW project in Palm Springs developed by Enron and a 2.1-MW project in San Gorgonio developed for Green Mountain Energy. Both of these projects also received production incentives from the new renewables account. A number of the state's municipal utilities, including Los Angeles and Sacramento, have also offered, and continue to offer, green power options to customers. However, these programs have had little impact on in-state wind energy development because they have been supplied from wind resources in Wyoming or the Pacific Northwest or other renewable energy sources, such as landfill gas.

\section{Market Factors}

The California electricity crisis of 2000/2001 effectively halted all new wind energy development due to the uncertainties of the market and a lack of creditworthy buyers. In an effort to remedy this problem, the state took a number of actions. First, the state authorized the Department of Water Resources (DWR) to enter into long-term contracts for new wind energy. Several new projects were developed as a result, including the 66.6-MW Mountain View projects, the 41-MW Cabazon project, and the 61.5-MW Whitewater Hill project. ${ }^{18}$ Later, in 2001, it created the California Power Authority (CPA), which established a goal of contracting

\footnotetext{
${ }^{15}$ Bolinger, et al., 2001

${ }^{16}$ Bolinger, M. and R. Wiser; Utility-Scale Renewable Energy Projects: A Survey of Clean Energy Fund Support, Lawrence Berkeley National Laboratory (LBNL 49667), May 2002

http://eetd.lbl.gov/ea/EMS/reports/49667.pdf

${ }^{17}$ Center for Resource Solutions, 1999 Green-e Verification Results, San Francisco, September 2000 http://www.green-e.org/pdf/99vr.pdf, accessed February 27, 2003.

${ }^{18}$ For more information on the DWR contracts, see http://wwwcers.water.ca.gov/contracts.html accessed April 30, 2003.
} 
for 1,000 MW of renewable energy, primarily wind and biomass projects, by the summer of 2002. ${ }^{19}$ However, no new projects were implemented as a result because of the CPA's inability to issue bonds. In addition, the California Energy Commission held two $\$ 40$ million production incentive auctions for new renewable resources in the fall of 2000 and the summer of 2001, with special incentives for projects that could come on-line quickly to help the supply problem. Because the developers of the winning projects could not obtain power purchase agreements, none of the wind projects were built. Finally, most existing wind energy facilities, as well as other qualifying renewable energy facilities, were able to renegotiate fixed-price PURPA contracts for energy output at favorable rates of $5.37 \mathrm{\phi} / \mathrm{kWh}$. Aside from the projects that were able to negotiate power purchase contracts, the uncertainty created by the restructuring debacle largely stifled wind energy development in the state and limited the effectiveness of the financial incentives available through the systems benefits fund.

\section{Policies Driving Future Development}

In the near term, growth will be facilitated by the extension of the system benefits funds and, more importantly, the creation of a renewable portfolio standard.

The system benefits funds were extended through 2012, when Governor Gray Davis signed AB 995 into law in 2000. The new funds, starting at \$135 million annually in 2002 and adjusted over time, ${ }^{20}$ are to be allocated to place greater emphasis on supporting new renewable sources rather than existing sources. The investment plan (SB 1038) calls for about half of the funds (up to a maximum of $\$ 347.6$ million) to be applied to new resources, with only $20 \%$ of the total funds to be spent on existing renewables. ${ }^{21}$ The funds allocated for existing renewables will be distributed as before in the form of a production incentive with a cap of $1.0 \phi / \mathrm{kWh}$ and a target price of $3.8 \notin / \mathrm{kWh}$. However, only $25 \%$ of the $\$ 27$ million will be available for existing wind projects (Tier 2 facilities). Facilities with fixed-price contracts above the target price of $3.8 \notin / \mathrm{kWh}$ are not eligible for incentives, which is likely to exclude facilities that renegotiated PURPA contracts during the electricity crisis. ${ }^{22}$ Although the rules for the new renewables account are still under development, utilities will be allowed to tap the funds to cover any abovemarket costs of procuring the renewable power mandated under the recently adopted RPS.

The RPS, which was signed into law (SB 1078) by the governor in the fall of 2002, requires the state's three investor-owned utilities to obtain $20 \%$ of their power from renewable sources by 2017. Each utility must increase its renewable portfolio percentage by at least $1 \%$ per year until $20 \%$ standard (RPS) is met. ${ }^{23}$ Public utilities are also required to design and implement their own RPS standards, but are given greater latitude about how to do so. Rules governing the implementation of the RPS are under development, so enforcement penalties, verification mechanisms, and other details have yet to be determined. The RPS is, however, one of the most aggressive in the nation, ultimately requiring on the order of 2,900 average MW of new renewable energy generation. However, the requirement may be scaled back if the state's system

\footnotetext{
${ }^{19}$ State Renewable Energy News, Volume 10, Number 3, Fall 2001. Prepared by the National Renewable Energy Laboratory, Golden, Colorado, for the National Association of Regulatory Utility Commissioners. http://www.nrel.gov/analysis/sren/sren30.html

${ }^{20}$ Bolinger, et al., 2001

${ }^{21}$ California Energy Commission, Draft Overall Program Guidebook for Renewable Energy Program, December 2002. http://www.energy.ca.gov/renewables/02-REN-1038/documents/2002-12-03 DRAFT OVERALL.PDF

${ }^{22}$ California Energy Commission, Existing Renewable Facilities Program Guidebook, P500-03-002F, February 2003. http://www.energy.ca.gov/renewables/guidebooks/500-03-002F.PDF

${ }^{23}$ State Renewable Energy News, Volume 11, No. 3, Fall 2002. Prepared by the National Renewable Energy Laboratory for the NARUC Renewable and Distributed Resources Subcommittee. http:/www.nrel.gov/analysis/sren/sren33.html
} 
benefits funds are found to be insufficient to support this level of capacity. Nevertheless, wind is likely to be used to meet a significant portion of the standard, and thus, the RPS is expected to be the most significant driver of new wind power development in the state and perhaps nationally.

\section{Texas}

Texas has 1,096 MW of installed wind energy capacity (see Table 3), which places it second among all states behind California. Most of the capacity has come on-line in the past few years, with the bulk installed in 2001. The main factors that have driven wind energy development in Texas are the state's RPS requirement; low-cost wind energy; and, to a lesser extent, customer demand for renewable energy. Compliance with the RPS, which requires the installation of 2,000 MW of new renewable capacity by 2009, is significantly ahead of schedule, as about $750 \mathrm{MW}$ of wind generation have been installed ostensibly to meet the standard since 1999. The success of the RPS is due in part to the state's high-quality wind resource, effective implementation, and strong support from the legislature and the Public Utility Commission.

TABLE 3: TEXAS INSTALLED WIND ENERGY CAPACITY

\begin{tabular}{|l|c|c|l|}
\hline \multicolumn{1}{|c|}{ Project } & Size in MW & Date Installed & \multicolumn{1}{c|}{ Power Purchaser } \\
\hline Nichols Station & 0.3 & 1992 & Southwest Public Service \\
\hline Culberson County & 35.0 & 1995 & Lower Colorado River Authority \\
\hline Big Spring I Howard County & 27.7 & 1999 & TXU Electric \& Gas \\
\hline Big Spring II Howard County & 6.6 & 1999 & TXU Electric \& Gas / York \\
\hline Culberson County & 30.0 & 1999 & Reliant Energy HL\&P/ LCRA \\
\hline Fort Davis Wind Farm 3. Fort Davis & 6.0 & 1999 & West Texas Utilities Co. \\
\hline $\begin{array}{l}\text { Southwest Mesa Wind Farm, Crockett } \\
\text { County }\end{array}$ & 74.9 & 1999 & \\
\hline Fort Stockton & 3.5 & 2001 & Texas - New Mexico Power \\
\hline $\begin{array}{l}\text { Hueco Mountain Wind Ranch, El Paso } \\
\text { County }\end{array}$ & 1.3 & 2001 & El Paso Electric \\
\hline King Mountain Wind Ranch & 278.2 & 2001 & $\begin{array}{l}\text { Texas-New Mexico Power Co. / } \\
\text { Reliant Energy / Austin Energy }\end{array}$ \\
\hline $\begin{array}{l}\text { Llano Estacado Wind Ranch at White } \\
\text { Deer }\end{array}$ & 80.0 & 2001 & SW Public Service \\
\hline Pecos Co near Iraan (Desert Sky) & 160.0 & 2001 & $\begin{array}{l}\text { City Public Services of San } \\
\text { Antonio }\end{array}$ \\
\hline Pecos County (Indian Mesa) & 82.5 & 2001 & $\begin{array}{l}\text { TXU (31.5MW), LCRA } \\
\text { (48.5MW) }\end{array}$ \\
\hline Trent Mesa, Trent (near Abilene) & 150.0 & 2001 & TXU Electric \& Gas \\
\hline Woodward Mt. I \& II, Pecos County & 159.7 & 2001 & TXU Electric \& Gas \\
\hline Total & 1095.7 & & \\
\hline
\end{tabular}

\section{Deliberative Polling}

Deliberative polling laid some of the groundwork for the development of the RPS in Texas by showing utilities and regulators that customers were interested in renewable energy. This form of polling is designed to determine informed public opinion by providing participants with an opportunity to learn about, discuss, and ask questions concerning a specific issue. Between 1996 and 1998, eight electric utilities in Texas polled their customers to identify which energy options they preferred for meeting future electric demand. ${ }^{24}$ The results showed that in addition to being concerned about stable, long-term low costs for energy, participants wanted more renewable

\footnotetext{
${ }^{24}$ Lehr, R., et al.; Listening to Customers: How Deliberative Polling Helped Build 1,000 MW of New Renewable Energy Projects in Texas, National Renewable Energy Laboratory, June 2003. NREL/TP-620-33177 http://www.eere.energy.gov/greenpower/pdf/33177.pdf
} 
energy and energy efficiency options. The level of customer support for these options and their willingness to pay for them surprised the utilities and regulators, many of whom attended the meetings. Based on responses indicating that 81 percent of customers were willing to pay one dollar more each month to support renewable energy, CSW proposed, and the utility commission approved, a $70 \mathrm{MW}$ wind project that added 25 cents to customers' bills. ${ }^{25}$

\section{Renewable Portfolio Standard}

With political support created in part through the deliberative polling process, the RPS was adopted in 1999 as part of Senate Bill 7, which opened the state's electric utility industry to competition. The legislation requires for-profit electricity retailers in the state (approximately 80 percent of the load in Texas) to collectively install 2,000 MW of new renewable energy capacity in addition to preserving the $880 \mathrm{MW}$ of capacity already on-line by 2009 . This translates to about $3 \%$ of current electricity supplies. Public utilities are exempt from the requirement unless they opt-in to competition.

The Texas RPS has resulted in the addition of a substantial amount of new wind power at reasonable cost and ahead of schedule, making it the most successful state RPS policies to date. By the end of 2002, more than 750 MW of recently installed wind capacity was purchased by utilities subject to the RPS or could be available to meet the requirement; whereas, the RPS capacity target for 2003 is $400 \mathrm{MW}$. Its success is due in part to the fact that Texas has its own power grid and the second best wind resource in the country. Most of the existing and planned wind farms are in West Texas where the average annual wind speeds are greater than $17 \mathrm{mph}$. With the combination of this strong resource and the federal production tax credit, some wind projects are generating electricity at or below 3 cents per $\mathrm{kWh}$. This makes wind-generated power competitive with new natural gas plants, even with low gas prices.

The RPS also has some specific characteristics that have made it particularly effective. Perhaps the most significant is that there are penalties for noncompliance, which give the policy some "teeth." It also features a credit trading system that allows utilities to purchase renewable energy certificates (RECs) from wind energy generators to meet the goal. Some of the advantages of this trading mechanism are that it is a market-based approach to meeting the standard and it allows participants some flexibility in meeting their obligations. (For a more comprehensive analysis of the Texas RPS, see Wiser and Langniss, 2001) ${ }^{26}$

\section{Economics/Fuel Diversification}

At least two utilities that are not subject to the RPS have contracted for wind energy to diversify their fuel mix, incorporate low-cost resources, and increase their reliance on clean energy resources. For example, the Lower Colorado River Authority (LCRA) purchases a total of about $80 \mathrm{MW}$ of wind energy from two projects. The utility doubled its commitment to wind energy in 2000 when increases in natural gas prices made wind energy more economic. In a company press release, a utility spokesman said "we are making this commitment because it is the right thing to do environmentally and economically." 27 In addition, the city of San Antonio purchases the output of a $160 \mathrm{MW}$ wind project, which it includes in its overall resource portfolio.

\footnotetext{
${ }^{25}$ Lehr, R.; telephone communication., May 1, 2003.

${ }^{26}$ Wiser, R. and O. Langniss; The Renewable Portfolio Standard in Texas: An Early Assessment, Lawrence Berkley National Laboratory, November 2001. http://eetd.lbl.gov/ea/EMS/reports/49107.pdf

27 "LCRA More Than Doubles Its Stake in Renewable Wind Energy," news release, September 12, 2000. http://static.lcra.org/newsarchive/2000/09/renewable.html.
} 
Siting

Limited siting constraints have also helped facilitate the construction of large wind farms in Texas. There has not been much opposition to siting wind farms because they are located in the sparsely populated western areas of the state that have the strongest resource. Other large energy (oil and gas) projects have been developed in these areas and, generally, there is acceptance to such development in the region. Most wind energy projects have been developed on private land, which also simplifies siting requirements. Further, the permitting process in Texas involves fewer state agencies and is simpler than in many other states. ${ }^{28}$

\section{Green Power Marketing}

Consumer demand for green energy has also driven some wind energy development. The municipal utilities serving customers in Austin, San Antonio and El Paso all have green pricing programs supplied primarily with wind energy. Austin Energy's GreenChoice program has been particularly successful and has had the most impact among the green pricing programs on wind energy development in the state. Austin has contracted for nearly $90 \mathrm{MW}$ of wind capacity to serve customers in its GreenChoice program and has plans to purchase another $25 \mathrm{MW}$ in the near future. A key feature of the Austin program is that the green rate is fixed for 10 years, which is the duration of the utility's green power supply contracts, providing subscribers with a hedge against increases in the price of natural gas and other generation fuels. As a result, some customers have actually saved money by purchasing green power rather than conventional power. Although many utility green pricing programs have been targeted to residential consumers, about $50 \%$ of the Austin's green power sales are to businesses or other nonresidential customers. Its success with the non-residential sector has made Austin the leading program in the United States in terms of annual green power sales. The program was developed in response to a 1999 resolution adopted by the Austin City Council calling for 5\% of Austin's electricity to come from renewable sources by 2005 .

In addition, Green Mountain Energy offers a 100\% wind energy product to Texas customers who are eligible to switch suppliers in the state's competitive electricity market. According to one study, the company may be serving as many as 50,000 customers in Texas. ${ }^{29}$ More recently, TXU Energy and Strategic Energy began supplying large nonresidential customers in Texas, including Dyess Air Force Base and Kinko's, with wind energy equivalent to about 10 aMW. A number of green energy certificate marketers that operate nationally also purchase wind energy from Texas to supply their customers. One benefit of purchasing power through the Texas market is that the REC tracking system developed for the RPS enables marketers to more easily verify their purchases.

\section{Future Development}

The RPS will continue to drive wind power development in Texas in the long term. However, transmission constraints could slow the rate of development in coming years. With the rapid growth of the wind industry during the past three to four years, existing transmission capacity has been insufficient to handle the wind energy output; and, in fact, wind farms in West Texas have been curtailed due to transmission constraints. The Electric Reliability Council of Texas (ERCOT) has approved plans to alleviate this congestion, but it will take time do so. Consumer demand for green energy both in-state and out-of-state may also continue to drive some

\footnotetext{
${ }^{28}$ Sloan, M; Virtus Energy, personal communication, May 13, 2003.

${ }^{29}$ Main, T., T. Morstad, and L. Hall; Unplugging Texas' Most Powerful Polluters. Prepared for Public Citizen's Texas Office and SEED Coalition, July 2002. http://www.citizen.org/hot issues/issue.cfm?ID=345
} 
development, given that Texas has low-cost and abundant wind resources and a REC tracking system in place to facilitate verification.

\section{Iowa}

Iowa was an early pioneer in wind development. Although the state's wind resource ranks tenth in the nation, it ranks third in installed wind capacity. The state's Alternative Energy Law (Iowa Code 476.41) was particularly successful in sparking wind development in Iowa and the state offers some attractive tax incentives that benefit developers, including a property tax and sales tax exemption. About $50 \mathrm{MW}$ of Iowa's total $423 \mathrm{MW}$ (see Table 4) of installed wind capacity are serving the RPS requirements in neighboring Wisconsin. ${ }^{30}$ Good wind resources, political support, and a green power requirement that begins in 2004 may expand wind power in Iowa further in coming years.

TABLE 4: IOWA INSTALLED WIND ENERGY CAPACITY

\begin{tabular}{|l|c|c|l|}
\hline \multicolumn{1}{|c|}{ Project } & Size in MW & Date Installed & \multicolumn{1}{|c|}{ Power Purchaser } \\
\hline Spirit Lake & 1.0 & $1992 / 2001$ & Alliant/IES Utilities \\
\hline Sibley Wind Farm & 1.2 & 1997 & Alliant/IES Utilities \\
\hline $\begin{array}{l}\text { Iowa Dist. Wind Energy Project 2. } \\
\text { Algona }\end{array}$ & 2.3 & 1998 & Consortium \\
\hline Waverly I,II,III & 2.4 & $1999 / 2001$ & Waverly Light \& Power \\
\hline Clear Lake (Cerro Gordo) & 42.0 & 1999 & Alliant / FORAS / FPL Energy \\
\hline $\begin{array}{l}\text { Storm Lake I Buena Vista \& Cherokee } \\
\text { Counties }\end{array}$ & 112.5 & 1999 & MidAmerican \\
\hline $\begin{array}{l}\text { Storm Lake II BuenaVista \& Cherokee } \\
\text { Counties }\end{array}$ & 80.3 & 1999 & Alliant/ IES Utilities \\
\hline Worth County (Top of Iowa Wind Farm) & 80.1 & 2001 & Alliant/ IPC \\
\hline Hancock County Wind Farm & 97.7 & 2002 & Alliant Energy (44 MW) \\
\hline Total & $422.7 *$ & & \\
\hline *Includes projects under 1 MW not listed. & \multicolumn{5}{|l}{} \\
\hline
\end{tabular}

\section{Alternative Energy Law}

Iowa's Alternative Energy Production Law, its version of the RPS, was largely responsible for sparking initial wind development in the state. Under the law, the state's two investor-owned utilities were required to secure a combination of 105 average MW (aMW) of renewable energy, with each utility's portion based on its percentage of the total retail electricity supplied in 1982. The Iowa legislature was the first to pass this type of renewable energy requirement, but legal challenges delayed implementation for a number of years. The original law was passed in 1983; and after delays and challenges, it was amended in 1990 to include the 105 aMW goal but with no timeline for implementation. Then in August 1996, the Iowa Utilities Board ordered the affected utilities to put contracts for renewable energy in place within six months. The utilities complied by entering into wind power purchase agreements for approximately $250 \mathrm{MW}$ of Iowabased wind capacity. The three projects installed in 1999 to meet the requirement were the 112MW Storm Lake I, the 42-MW Clear Lake, and the 80-MW Storm Lake II project. ${ }^{31}$

The original intent of the law was to encourage small developers to build and own the wind farms that would meet the 105 aMW goal. For this reason, the state's large utilities were prohibited from owning large wind projects. However, other large utilities were not prohibited from entering the wind market and, consequently, many out-of-state utilities currently own the

\footnotetext{
${ }^{30}$ Dunlop, J.; American Wind Energy Association, e-mail communication, May 1, 2003.

${ }^{31}$ Porter, K; Exeter \& Associates, personal communication, April 15, 2003.
} 
existing wind farms. In April 2003, Governor Tom Vilsack signed legislation modifying the provision to allow in-state utilities to own renewable energy facilities. Soon after this, Mid American (a utility that operates in Iowa) announced plans to develop $310 \mathrm{MW}$ of wind by $2006^{32}$

\section{Renewables Portfolio Standards in Neighboring States}

Another significant driver for wind development in Iowa has been RPS policies in neighboring states. About $50 \mathrm{MW}$ of Iowa's total $423 \mathrm{MW}$ of installed wind capacity are being used to meet the Wisconsin RPS. For example, Alliant Energy (which serves customers in both Iowa and Wisconsin) purchases power from the $80 \mathrm{MW}$ Top of Iowa wind farm in Worth County to meet the Wisconsin standard. ${ }^{33}$ Wind projects in Iowa were selected because of the state's superior wind resource, fewer siting problems, and the availability of transmission to deliver the power to Wisconsin.

\section{Local Option Property Tax Assessment}

Iowa has a property tax exemption for wind farms that helps lower the cost of wind energy generation. A law enacted in 1999 (Iowa Code 427B.26, 441-21) allows counties and local tax jurisdictions in Iowa to assess property tax on wind farms at a special discounted rate; however, those who choose to do so must adhere to state guidelines. In year 1, the wind turbines are assessed at zero percent of their true value. In years 2 through 6 the rate increases by 5 percent annually until it reaches a maximum of 30 percent in the seventh year. For example, in Cerro Gordo County, the $42 \mathrm{MW}$ of installed wind capacity had a true value of \$42.5 million in 2001, the second assessment year of the project. Instead of being taxed on this amount, the special assessment rate of 5 percent in year 2 brought the taxable value down to only \$2.1 million. Although this incentive is significant, it is probably not sufficient to drive development on its own.

\section{Sales Tax Exemption}

Iowa also exempts wind energy equipment from the state sales tax. The exemption covers all materials used to develop, install, or construct wind energy systems, but does not apply to equipment for building a turbine manufacturing plant. Without this incentive, turbines and equipment related to constructing a wind project would be subject to a 5 percent state sales tax. In addition, and depending on the county, equipment might also be subject to a 1 percent local sales tax and a 1 percent local school tax. According to some developers, sales tax exemptions can be significant because turbines are a large percentage of the overall cost of a project. However, when asked whether sales or property tax exemptions could make or break a deal, one developer said probably not — but that they are helpful to have as a part of the overall policy package. $^{34}$

\section{Green Pricing Programs}

About $6 \mathrm{MW}$ of wind energy capacity is supported partly through green power marketing in Iowa. A number of utilities currently offer green pricing programs, including Cedar Falls Utilities, Alliant Energy, and a number of electric cooperatives served by Basin Electric. Cedar Falls owns 1.5 MW of wind generation that it has marketed to its customers since 1998;

\footnotetext{
${ }^{32}$ Mid American Energy news release, "Gov. Vilsack Signs Legisaltion Enabling Construction of Mid American Energy’s Proposed Wind Project," April 11, 2003. http://www.midamerican.com/newsroom/asp/newsdetails.asp?id=197\&nav=1

${ }_{33}$ Porter, K; Exeter \& Associates, personal communication, April 15, 2003.

${ }^{34}$ Hutchinson, E.; Zilkha Renewable Energy, telephone communication, April 8, 2003.
} 
currently about $3 \%$ of its customers participate in the utility's green pricing program. Alliant uses about 1.3 MW of Iowa wind power to supply its Second Nature program, which is offered in Iowa, Minnesota, and Wisconsin. About 7,000 customers in the three states currently participate. And Waverly Light \& Power markets a portion of the renewable energy certificates associated with its wind energy output to both wholesale and retail customers nationally. Waverly installed a $1.5 \mathrm{MW}$ wind project in 1999 and another $900 \mathrm{~kW}$ turbine in 2001.

Green pricing may play a larger role in future wind development in 2004, when all utilities will be required by law to offer renewable energy options to their customers. The law applies to all power providers in the state, regardless of whether the Iowa Utilities Board regulates them.

\section{Schools}

A number of school districts in northwestern Iowa rely on wind turbines to supply power and offset some of their energy costs. Currently, eight school districts in Iowa own turbines with a combined total capacity of 3.6 MW. In fact, the state's first large turbine was installed in the Spirit Lake School District in 1993. It is still operating and saves the district more than $\$ 24,000$ each year in electricity costs. ${ }^{35}$ According to the Iowa Energy Bureau, the experience at Spirit Lake inspired the other schools to follow suit. The schools consider the turbines useful not only to offset some electricity demand, but they also view them as environmentally desirable, as well as an education tool. ${ }^{36}$

\section{Future Development}

Factors that may influence future wind energy development in Iowa include political support from the governor and a state law requiring all utilities to implement green pricing programs by 2004. Governor Vilsack strongly supports wind power and recently declared that he wants to see an additional 1,000 MW of wind in the state. One utility has responded to the goal by announcing plans to develop $310 \mathrm{MW}$ of new wind power by 2006. If completed, the project would nearly double the state's current wind generating capacity.

\section{Minnesota}

Minnesota has a strong wind resource and ranks fourth in the nation with $336 \mathrm{MW}$ (see Table 5) of installed capacity. The main driver for wind development has been a settlement requiring Xcel Energy to develop or purchase $825 \mathrm{MW}$ of wind power in exchange for the right to store waste from its Prairie Island nuclear power plant. Of this, $305 \mathrm{MW}$ is installed and another $160 \mathrm{MW}$ is expected to be operational by the end of 2003. Another $400 \mathrm{MW}$ is expected to come on-line by about 2006. Although this requirement has been driving most large-scale wind energy development in the state, Minnesota also has a number of policies and incentives that encourage investments in wind energy, including a production incentive for small wind, a sales tax exemption, mandatory green pricing, and a renewable energy fund. Future development will be largely driven by a recent state law that sets a goal for all utilities to obtain $10 \%$ of their electricity from renewable sources by 2015. The standard is mandatory for Xcel Energy.

\footnotetext{
${ }^{35}$ Iowa Department of Revenue Web site, accessed March 24, 2003. http://www.state.is.us/dnr/energy/pubs/renewable/rcase/rcase01.htm

${ }^{36}$ Tahtinen, S; Iowa Energy Bureau, personal communication, May 2, 2003.
} 
TABLE 5: MINNESOTA INSTALLED WIND ENERGY CAPACITY

\begin{tabular}{|c|c|c|c|}
\hline Project & Size in $\mathrm{MW}$ & Date Installed & Power Purchaser \\
\hline Buffalo Ridge & 25.0 & 1994 & Xcel \\
\hline Lake Benton & 210.8 & $1998 / 1999$ & Xcel Energy \\
\hline Chandler Hills & 5.9 & $1998 / 2001$ & Great River Energy \\
\hline Moorhead & 1.5 & $1999 / 2001$ & Moorhead Public Service \\
\hline Lakota Ridge & 11.3 & 1999 & Xcel \\
\hline Shaokatan Hills & 11.9 & 1999 & Xcel Energy \\
\hline Woodstock & 10.2 & 1999 & Xcel Energy \\
\hline Dispersed Project & 5.9 & 2000 & Xcel Energy \\
\hline North Shaokatan Wind Farm & 11.9 & 2000 & Xcel Energy \\
\hline Agassiz Beach & 2.0 & 2001 & Xcel Energy \\
\hline Pipestone County, Kas Farms & 1.5 & 2001 & Xcel Energy \\
\hline Pipestone, Olsen Wind Farm & 1.5 & 2001 & Xcel Energy \\
\hline Ruthton Wind Farm & 15.8 & 2001 & Xcel Energy \\
\hline Wilmont Hills & 1.5 & 2001 & Alliant Energy \\
\hline Dodge Center, McNeilus & 9.0 & 2002 & Xcel Energy \\
\hline MinWind I \& II & 3.8 & 2002 & Alliant Energy \\
\hline $\begin{array}{l}\text { Missouri River Energy Services (MRES), } \\
\text { Worthington }\end{array}$ & 3.6 & 2002 & $\begin{array}{l}\text { MRES/ Worthington Public } \\
\text { Utilities }\end{array}$ \\
\hline Total & $335.9 *$ & & \\
\hline
\end{tabular}

\section{Renewables Set Aside/Renewable Energy Goal}

The initial driver for wind power development in Minnesota involved a nuclear waste settlement. In exchange for the right to store spent nuclear fuel rods at its Prairie Island Nuclear Plant, the Minnesota Legislature required Xcel Energy (formerly Northern States Power) to construct or purchase $425 \mathrm{MW}$ of wind power and $125 \mathrm{MW}$ of biomass power by December 31, 2001. In 1999, the PUC, as authorized in the original 1994 law, ordered Xcel to secure an additional 400 MW of wind power by December 31, 2012. By the end of 2002 the utility had met the first portion of this requirement by contracting for a total of $467 \mathrm{MW}$ of wind. Approximately 305 MW is currently installed and the remaining capacity is expected to be operational by the end of 2003.

In June 2003, Governor Pawlenty signed into law a bill (HF 9) requiring Xcel to obtain at least 10 percent of its supplies from renewable resources by 2015, and calling for other utilities to voluntarily meet the same standard. The law also calls for Xcel to install at least $300 \mathrm{MW}$ of wind power, including $100 \mathrm{MW}$ of small wind projects of less than $2 \mathrm{MW}$, to meet the standard. Other utilities are required to submit plans to the public utility commission for meeting the goal. Great River Energy, a wholesale supplier for a number of rural electric cooperatives in the state, has already indicated that it plans to install $100 \mathrm{MW}$ of wind to meet the goal.

\section{Production Incentive}

Minnesota also has a production incentive for small wind energy facilities that has led to substantial investment in small wind turbines. One of the few state-level production-based incentives, it is similar to the federal production tax credit in that it offers incentives for actual power generation. But, unlike the PTC, a project owner need not have tax liability in order to take advantage of it. From July 1997 to December 2004, new wind projects of up to $2 \mathrm{MW}$ in size are eligible to receive $1.5 \mathrm{c} / \mathrm{kWh}$ for power generated during the first 10 years of operation. 
Since these payments do not reduce the capital cost of a project, they do not offset the federal production tax credit. Originally, the incentive was available to the first $100 \mathrm{MW}$ of eligible projects brought on-line. The cap was nearly reached, which indicates the importance of this incentive for supporting small wind development. In 2003, Governor Pawlenty signed into law a bill (HF 9) extending the cap to $200 \mathrm{MW}$.

\section{Utility Green Pricing}

Utility green pricing programs have also played a role in encouraging wind energy investment in the state. The earliest utility programs appeared in 1997 and 1998. And then, in 2001, Minnesota adopted legislation (SB 722), requiring all utilities to offer green power options to their customers. As a result, there are more than 80 utilities in the state that offer green pricing programs - and most of these are supplied with wind power. Collectively, about $14 \mathrm{MW}$ of new wind capacity has been developed by utilities such as Moorhead Public Service (1.5 MW), Great River Energy (6 MW), and Missouri River Energy Services (3.6 MW) to meet consumer demand. The Moorhead program has been particularly successful in terms of consumer response, with about 6 percent of its customers participating in the program. This represents the highest participation rate achieved by any U.S. green pricing program.

\section{Sales tax}

Another incentive that lowers the cost of wind generation is the state's sales tax exemption for wind turbines and the materials used to manufacture, install, construct, repair, or replace them. Without this exemption, such materials would be subject to a sales tax of 6.5 percent. One developer with projects in Iowa reported that while a sales tax exemption is helpful because wind turbine equipment is expensive, it probably will not make or break a deal. ${ }^{37}$

\section{Renewable Development Fund}

The Minnesota renewable development fund (RDF), which is similar to other states' system benefits funds, is used primarily to support innovative, small-scale renewable energy projects. Therefore it has not and is not expected in the future to drive a significant amount of wind energy development. In 2003, the state legislature doubled the amount that Xcel must pay into the fund each year from about $\$ 8.5$ million to $\$ 16$ million. In July 2001, Xcel issued its first solicitation for renewable energy grant proposals. Eight projects were selected for funding, including two wind projects totaling about $6 \mathrm{MW}$. The first is a cooperative wind project financed by individuals who purchase shares in the project and earn a return on their investment. The RDF is to provide about $\$ 900,000$ in funding for the project in the form of a five-year incentive payment (equivalent to about $1 \notin / \mathrm{kWh}$ ). The other winning proposal was for a $900 \mathrm{~kW}$ turbine to be installed at a local school, which will receive about $\$ 750,000$ in funding in the form of a fiveyear incentive payment of about $5.8 \mathrm{c} / \mathrm{kWh}$. In the future, the RDF may provide less support for wind energy projects, as greater preference may be given to biomass projects. ${ }^{38}$

\section{Production Tax/Property Tax Exemption}

All real and personal property associated with wind power generation is exempt from property tax; however, in lieu of a property tax, a production tax on wind systems was established in 2002. Systems larger than $12 \mathrm{MW}$ are taxed at a rate of 0.12 cents $/ \mathrm{kWh}$; those between $12 \mathrm{MW}$ and $2 \mathrm{MW}$ are taxed at a rate of 0.036 cents $/ \mathrm{kWh}$; and those between $0.25 \mathrm{MW}$ and $2 \mathrm{MW}$ are

\footnotetext{
${ }^{37}$ Hutchinson, E.; Zilkha Renewable Energy, telephone communication, April 8, 2003.

${ }^{38}$ Wiser, R.; "An Open-Ended Renewables RFP in Minnesota Funds Biomass and Innovative Wind Applications," Case Studies of State Support for Renewable Energy, Lawrence Berkeley National Laboratory, September 2002.
} 
taxed at a rate of 0.012 cents $/ \mathrm{kWh}$. Small wind systems less than $0.25 \mathrm{MW}$ in size are exempt from the production tax. Minnesota statute allows the local tax jurisdiction to set a lower tax rate in order to attract wind development. This policy provides some modest benefits to wind energy developers because it removes some of the risk associated with a project by basing the tax on actual output, as opposed to value. Therefore, the tax over the life of the project can be more easily estimated.

\section{Future Development}

In the future, state mandates will continue to drive wind energy development in Minnesota. By the end of 2003, another $160 \mathrm{MW}$ of wind generation is expected to be operational, satisfying the conditions of the nuclear waste settlement agreement. In addition, the timeline for the installation of the additional $400 \mathrm{MW}$ originally required by 2012 may be accelerated as a result of a recent transmission-related decision by the Minnesota PUC. In the decision, the PUC granted Xcel a "certificate of need" for new transmission lines to run from the Buffalo Ridge wind site to the Twin Cities area, subject to the condition that Xcel must install the $400 \mathrm{MW}$ of wind capacity at the same time that the lines are completed in 2006. In the longer term, Xcel will need to install additional capacity, including at least $300 \mathrm{MW}$ of wind energy, to meet the recently adopted requirement that 10 percent of its supplies come from renewable sources. While other utilities are not specifically required to meet the standard, they are required to develop plans for meeting the goal, and some have taken preliminary action develop new renewables. To a lesser extent, utility green pricing programs may continue to drive some wind energy development in the future as new programs install capacity to serve their customers. And given that cap on the small wind production incentive was recently extended, it will likely to continue to drive investment in small wind projects in the state.

\section{Oregon}

As of the end of 2002, a total of 219 MW (see Table 6) of wind power capacity was installed in Oregon. A variety of factors have encouraged wind power development, including market conditions that have been very favorable to wind; the ability to construct low-cost, large-scale projects with wind energy costs reportedly as low as $2.5 \phi / \mathrm{kWh}$ in some cases; utility commitments; and consumer demand for green power. Settlement agreements were an initial driver for wind energy investment, while integrated resource-planning requirements may play a larger role in future development. Funds collected through the state's systems benefit charge may also play a more significant role in supporting future wind development given that market prices have declined. The lack of sales tax in the state and, to some extent, property tax incentives have also helped to lower the cost of wind energy generation.

TABLE 6: OREGON INSTALLED WIND ENERGY CAPACITY

\begin{tabular}{|l|c|c|l|}
\hline \multicolumn{1}{|c|}{ Project } & Size in MW & Date Installed & \multicolumn{1}{c|}{ Power Purchaser } \\
\hline Vansycle Ridge (Helix, OR) & 25.1 & 1998 & Portland General Electric \\
\hline $\begin{array}{l}\text { Condon Wind Project Phase I (Gilliam } \\
\text { County) }\end{array}$ & 24.6 & 2001 & Bonneville Power Administration \\
\hline Klondike (Wasco) & 24.0 & 2001 & Northwest Wind Power \\
\hline Stateline Wind Project (Umatilla) & 83.2 & 2001 & PacifiCorp \\
\hline $\begin{array}{l}\text { Condon Wind Project Phase II (Gilliam } \\
\text { County) }\end{array}$ & 25.2 & 2002 & Bonneville Power Administration \\
\hline Stateline (Orphans) & 37.0 & 2002 & NA \\
\hline Total & 219.1 & & \\
\hline
\end{tabular}




\section{Settlement Agreements}

Oregon's first commercial-scale wind power project was the 25-MW Vansycle Ridge project developed by FPL Energy for Portland General Electric (PGE) in 1998. The project stemmed from a 1993 agreement in which PGE committed to develop renewable energy generation to replace a closed nuclear plant. Vansycle Ridge was one of three projects selected in response to an RFP issued by the utility for $100 \mathrm{aMW}$ of renewable energy. However, development did not move forward until the utility made another commitment to purchase power from the project, as part of the settlement agreement for its merger with Enron in 1997. ${ }^{39}$ Strong support from renewable energy advocates was an important contributor to the successful completion of the project. PGE includes the power in its overall generation portfolio, which is paid for by all customers in the utility's rate base. The Vansycle Ridge site was selected, in part, because of its favorable wind resources, compatible land use, and ease of interconnection with the Bonneville Power Administration transmission lines. ${ }^{40}$

\section{Economics/Market Conditions}

After the construction of the Vansycle Ridge project, there was a several-year lag in wind energy development until three commercial-scale projects totaling about $130 \mathrm{MW}$ were installed in 2001. Wind power development accelerated at that time to meet regional capacity shortages, caused by a drought that reduced the output of the region's substantial hydropower resources, as well as the California electricity crisis. Historically, Oregon has relied on imports of fossil-fuel generated power from California to meet its winter peak when hydropower production declines, and has exported excess hydropower production to meet California's peak demand in the summer months. When the California restructuring debacle occurred in 2000 and 2001, the resulting power shortages and exceptionally high wholesale electricity and natural gas prices affected power supplies throughout the region.

Amidst these market conditions, Bonneville Power Administration (BPA) issued a request for proposals seeking about 1,000 MW of new wind power. In its request, BPA explained that "wind projects are particularly attractive because they can come online in a relatively short time (24 to 30 months), offer power that is competitively priced with other sources such as combustion turbines, are relatively easy to site and expand, have low environmental impacts (including no carbon emissions) and are highly desirable to buyers of 'green' power." 41 In addition, BPA also recognized that wind energy could be used in conjunction with hydropower to serve as a form of energy storage in times of drought, allowing hydropower facilities to operate at reduced output levels when wind is available.

In response to the RFP, BPA received 25 wind energy proposals totaling 2,600 MW and selected seven projects in Washington and Oregon with a combined capacity of $830 \mathrm{MW}$. DOE announced that the average first-year cost of the wind power was expected to be less than $\$ 30$ per megawatt-hour. ${ }^{42}$ However, not all of this capacity has come on-line because demand for power has declined in the region as the economy has slowed, the California market has come

\footnotetext{
${ }^{39}$ Shimshak, R.; Renewable Northwest Project, personal communication, May 5, 2003.

${ }^{40}$ AWEA news release, "Major Wind Farm in Pacific Northwest Begins Operation," December 3, 1998.

http://www.awea.org/news/wpa2.html

${ }^{41}$ BPA news release, "BPA Solicits New Wind Power Projects," February 22, 2001.

http://www.bpa.gov/Corporate/KC/home/nreleases/01nr/nr022201x.shtml

${ }^{42}$ BPA news release, "Wind Prospectors are Knocking on Doors Looking to Mine the Wind," September 20, 2001. http://www.bpa.gov/Corporate/KC/home/nreleases/01nr/nr092001A.shtml. DOE news release, "Secretary Abraham Announces Major Wind Power Initiative to Aid Western Energy Shortage," June 25, 2001. http://www.energy.gov/HQPress/releases01/junpr/pr01104.htm
} 
under control, and power prices have dropped. As of the end of 2002, BPA was purchasing power from wind projects in the region totaling about $180 \mathrm{MW}$, including the Condon (50 MW) and Klondike (24 MW) projects in Oregon, as well as $90 \mathrm{MW}$ of the 300-MW Stateline project, which straddles the Washington-Oregon border.

The Stateline project was also brought on-line during the period of power shortages and high wholesale power prices. Developed by PacifiCorp Power Marketing, it is a merchant plant with wind energy generation costs reported to be as low as $2.5 \mathrm{c} / \mathrm{kWh}$. The combination of a good wind resource, economies of scale, high wholesale electricity prices, at least initially, and state and federal financial incentives enabled the project to move forward.

\section{Green Power Demand}

Demand for green power has also played a role in supporting wind energy projects in the Pacific Northwest. Under an agreement with the non-profit Bonneville Environmental Foundation (BEF, BPA sells the power from its renewable facilities at market rates, while BEF sells green tags representing the environmental attributes to cover the above-market costs of generating the renewable power. BEF uses the revenues to expand a $\$ 15$ million fund earmarked for renewable resource development in the Pacific Northwest. ${ }^{43}$ During 2002, approximately $20 \mathrm{MW}$ of wind energy was marketed to utilities and other consumers through BEF.

State policies in Oregon and Washington requiring utilities to offer green pricing programs have increased the number of offerings and helped to stimulate consumer demand for green power. Under Oregon's electric restructuring law, PacifiCorp and PGE are required to offer a renewable energy option to residential and commercial electricity customers. Implementation of this requirement led to a tripling in green energy subscriptions in just nine months, due perhaps in large part to the fact that the utilities teamed with green power marketer Green Mountain Energy to offer new product options. EWEB and two electric cooperatives in Oregon also offer green power options supplied primarily with wind. As noted earlier, EWEB and PacifiCorp obtain wind energy from facilities in Wyoming, while the other programs are supplied primarily from Oregon or Washington-based wind projects.

In Washington, state law requires all electric utilities that serve more than 25,000 meters to offer consumers a renewable energy purchase option. To date, 17 utilities offer green power programs and most of these are supplied from wind resources in the Pacific Northwest. In aggregate, utility green pricing programs in Washington and Oregon support about $10 \mathrm{aMW}$ of wind (about 30 MW of nameplate). Municipal utilities in Sacramento and Los Angeles also purchase power from the Stateline project to supply their green pricing programs.

Commitments by municipalities to increase reliance on renewable sources are also supporting wind energy projects in Oregon. For example, Seattle City Light contracted with PacifiCorp Power Marketing (PPM) to purchase about $50 \mathrm{MW}$ from the Stateline Project in 2002 to comply with a city council resolution to meet all future electricity needs with no net greenhouse gas emissions. ${ }^{44}$ The city plans to increase its purchases of wind power over time to as much as 175 MW by 2004. Similarly, Eugene's municipal utility contracted with PPM to buy between 20 and

\footnotetext{
${ }^{43}$ BPA news release, “BPA, BEF Ink 'Green Tag' Deal,” April 30, 2001. http://www.bpa.gov/Corporate/KC/home/nreleases/01nr/nr043001B.shtml

${ }^{44}$ U.S. DOE Green Power Network http://www.eere.energy.gov/greenpower/mkt customer.html\#seattlecl accessed March 6, 2002. City of Seattle news release, "Mayor Paul Schell Proposes Nation's Largest Purchase of Wind Power," September 17, 2001. http://www.cityofseattle.net/news/detail.asp?ID=2078
} 
$25 \mathrm{MW}$ of power annually for the next 25 years from the Stateline project to meet its goal of acquiring new renewable energy capacity equivalent to $1 \%$ of its total load each year. ${ }^{45}$

\section{State Financial Incentives}

An important financial "incentive" for wind power development in Oregon is the lack of state sales tax. Given the capital cost-intensive nature of wind energy development, avoiding state sales tax-typically on the order of $6 \%$ to $8 \%$ on perhaps $80 \%$ or more of an entire project's costs - results in significant savings. Although of lesser importance, another financial incentive available in Oregon is a business energy tax credit that allows businesses to take a $35 \%$ tax credit up to $\$ 100,000$ over five years for the construction of renewable energy systems. ${ }^{46}$ Because of its limited size, this policy has had minimal impact on development, however. ${ }^{47}$ Some wind projects have also been able to benefit from property tax incentives if they are constructed in areas designated as enterprise zones. In areas with such a designation, local counties are able to authorize property tax abatement for between three to five years. This has been important for some projects developed in areas with more modest wind resources, such as Condon. ${ }^{48}$

\section{Future Development}

In the future, financial incentives available through the state's renewable energy fund are expected to help drive new project development. Under the state's 1999 restructuring law, utilities offering customer choice are required to collect a surcharge on customer electric bills to support energy efficiency and renewable energy projects. The fund is estimated to be about $\$ 50$ million per year for 10 years, with about $\$ 8.6$ million of the total slated for the above-market costs of renewable energy. ${ }^{49}$ In its first effort to provide financial incentives for wind energy, the Energy Trust of Oregon, which administers the fund, issued an RFP in July 2002 requesting bids from developers for up to $100 \mathrm{MW}$ of wind capacity to be partially supported through the fund. The winning bid was for a 41-MW project outside of Pendleton, Oregon, which is to receive incentives totaling $\$ 3.8$ million, or about $0.35 \mathrm{c} / \mathrm{kWh}$ on a levelized basis over 20 years. ${ }^{50}$ The trust expects to provide additional incentives for wind energy projects in the future.

Future development may also be driven partly by the integrated resource planning process. In its 2003 Integrated Resource Plan (IRP), PacifiCorp proposed to meet its projected load growth during the next 10 years (2004-2014) by installing 4,000 MW of new generating capacity, including 1,400 MW of new wind. According to PacifiCorp, the plan includes a diversified resource mix because it is "expected to provide low-cost, low-risk and highly reliable sources of energy for customers while balancing social and environmental needs." ${ }^{, 51}$ In addition, PGE has proposed to install $5 \mathrm{aMW}$ of renewables (the equivalent of about $15 \mathrm{MW}$ of wind) during the next 10 years with financial support from the state's system benefits fund. ${ }^{52}$

\footnotetext{
${ }^{45}$ Northway, M.; EWEB, personal communication, August 21, 2002.

${ }^{46}$ AWEA, Inventory of State Incentives for Wind Energy in the U.S.: A State by State Survey, Washington, D.C., 2002. http://www.awea.org/policy/documents/inventory.PDF

${ }^{47}$ Roberts, R.; PacifiCorp Power Marketing, personal communication, April 22, 2003.

${ }^{48}$ Shimshak, R.; Renewable Northwest Project, personal communication, May 2003.

${ }^{49}$ Bolinger et al., 2001

${ }^{50}$ Energy Trust of Oregon news release, “Proposals Sought For New Wind Power in Oregon,” July 16, 2002. http://www.energytrust.org/about energy trust/library/news/renewables/WindPowerRFPNewsRelease.doc; West, P.; Energy Trust of Oregon, personal communication, (503) 493-888, ext. 209, March 7, 2003.

${ }^{51}$ PacifiCorp news release, "PacifiCorp Delivers Plan to Meet Customers' Future Energy Needs," January 26, 2003. http://www.pacificorp.com/Press_Release/Press_Release25040.html. See the entire 2003 Integrated Resource Plan at http://www.pacificorp.com/File/File25682.pdf.

52 Shimshak, R.; Renewable Northwest Project, personal communication, May 2003.
} 


\section{Washington}

In Washington, all of the state's $228 \mathrm{MW}$ (see Table 7) of wind energy capacity has come online in the past two years. As with Oregon, the primary factors driving wind power development have been market conditions that at least initially were favorable to wind, low-cost wind power, proactive utilities, demand for green power, and municipal and utility commitments to increase their reliance on wind power. Both the number of utility green pricing programs and sales of green power in the region have increased considerably in recent years, in part due to a state law requiring utilities to offer green power options. Washington also has tax incentives to encourage renewable energy development, the most important of which is a sales tax exemption.

TABLE 7: WASHINGTON INSTALLED WIND ENERGY CAPACITY

\begin{tabular}{|l|c|c|l|}
\hline \multicolumn{1}{|c|}{ Project } & Size in MW & Date Installed & \multicolumn{1}{c|}{ Power Purchaser } \\
\hline $\begin{array}{l}\text { Stateline Wind Project, Phase I (Walla } \\
\text { Walla) }\end{array}$ & 180.2 & 2001 & PacifiCorp \\
\hline Nine Canyon Wind Farm & 48 & 2002 & $\begin{array}{l}\text { Public Power Members of Energy } \\
\text { Northwest }\end{array}$ \\
\hline Total & 228.2 & & \\
\hline
\end{tabular}

\section{Economics/Market Conditions}

The Stateline project, which straddles the Washington-Oregon border, was the first commercialscale wind project developed in the state. About $180 \mathrm{MW}$ of the project was constructed in Washington in 2001. As discussed earlier, the project was constructed during a time of power shortages in the Pacific Northwest caused by a drought and regional repercussions from the California electricity crisis. Thus, economics and market conditions that were favorable to wind played a key role in successful completion of the project.

\section{Green Power Demand}

As noted earlier, the Stateline project is used to supply green power customers in the region. Washington law requires all electric utilities that serve more than 25,000 meters to offer voluntary green pricing programs to customers as of 2002. As a result, there are 17 utilities in Washington that offer green power options to their customers. Most of these are supplied from Stateline and other wind resources in the Pacific Northwest. In aggregate, utility green pricing programs in Washington and Oregon support about 10 aMW of wind (about 30 MW nameplate). In addition, municipal utilities in California, including those in Sacramento and Los Angeles, purchase power from the Stateline project to supply their green pricing programs.

\section{Municipal Utility Commitments}

In 2002, the $48 \mathrm{MW}$ Nine Canyon wind project became the largest wind power project owned by public power entities in the nation. The initial driver was the utilities' interest in obtaining power from cleaner energy sources and diversifying their resource portfolios. As the planning progressed, economics played a larger role as natural gas prices increased, making wind more cost-competitive. ${ }^{53}$ The project was developed by Energy Northwest, a municipal power supplier, and the output is purchased by eight public utilities - Benton, Chelan, Douglas, Grant, Grays Harbor, Lewis, Mason, and Okanogan PUDs. ${ }^{54}$ Several of the utilities use a portion of the wind power to supply customers who participate in their green pricing programs. Others have

\footnotetext{
${ }^{53}$ Miller, G; Energy Northwest, personal communication, May 5, 2003.

${ }^{54}$ For more information, see http://www.bentonpud.org/articles/nine-can_wind proj.htm or http://www.energynorthwest.com/What $\% 20 \mathrm{we} / \mathrm{NINECANmain.asp.}$
} 
included the wind power in their overall generation mix that supplies all ratepayers. Energy Northwest plans to add another $16 \mathrm{MW}$ to the facility in 2003.

\section{Sales Tax and Excise Tax Exemptions}

Washington also has financial incentives that encourage renewable energy development, including a sales tax exemption for wind and other renewable energy facilities and a corporate excise tax exemption for qualifying high technology manufacturers, including renewable energy developers. The corporate excise tax exemption applies without limit and sunsets on January 1, $2004 .^{55}$ Of the two, the sales tax exemption has been more important for developers because the cost of the turbines and other capital represent a large fraction of overall development costs.

\section{Future Development}

According to AWEA, approximately $440 \mathrm{MW}$ of wind capacity are planned for the short term; however, it is uncertain how much of this capacity will actually be developed. More stringent siting regulations and greater concerns over aesthetic issues may slow or impede future development activities. In the longer term, development may be driven in part by PacifiCorp, which has announced plans to use wind to meet a significant portion of its expected load growth. In its 2003 Integrated Resource Plan (IRP), the company proposed to meet its projected load growth during the next 10 years (2004-2014) by installing 4,000 MW of new generating capacity, including 1,400 MW of new wind. Puget Sound Energy has set a goal to meet at least 5 percent of customers' energy-supply needs with renewable resources by 2013 as part of its leastcost plan.

\section{Wyoming}

Wyoming's wind energy capacity grew from about $1 \mathrm{MW}$ in 1998 to about $140 \mathrm{MW}$ (see Table 8 ) by the end of 2002. The state's relatively low-cost wind energy resources have been used to meet consumer demand for green power and utility renewable energy purchase commitments in the surrounding region. Generation costs have been relatively low because of the state's strong wind resources and the ability to site relatively large projects that could be expanded over time. Of the total capacity installed, about $75 \mathrm{MW}$ is used to meet utility commitments to develop renewables as a result of mergers or integrated resource planning requirements. The rest supplies green power consumers and utility green pricing programs in Colorado, the Pacific Northwest, and California. There are no state policy incentives available for large-scale wind projects in Wyoming.

TABLE 8: WYOMING INSTALLED WIND ENERGY CAPACITY

\begin{tabular}{|l|c|c|l|}
\hline \multicolumn{1}{|c|}{ Project } & Size in MW & Date Installed & \multicolumn{1}{c|}{ Power Purchaser } \\
\hline Medicine Bow & 0.1 & 1996 & PRPA \\
\hline Medicine Bow, WY & 1.2 & 1998 & PRPA \\
\hline Foote Creek Rim - I (Carbon Co.) & 41.4 & 1999 & PacifiCorp, EWEB \\
\hline Foote Creek Rim - II (Carbon Co.) & 1.8 & 1999 & BPA \\
\hline Foote Creek Rim - III (Carbon Co.) & 24.8 & 1999 & Public Service Co of Colorado \\
\hline Medicine Bow & 3.3 & 1999 & PRPA \\
\hline Foot Creek Rim - IV (Carbon Co.) & 16.8 & 2000 & BPA \\
\hline Medicine Bow & 1.3 & 2000 & PRPA \\
\hline Arlington, Carbon Co. (Rock River I) & 50.0 & 2001 & PacifiCorp \\
\hline Total & 140.6 & & \\
\hline
\end{tabular}

\footnotetext{
${ }^{55}$ AWEA, 2002
} 


\section{Green Pricing}

The first utility-scale wind turbines were installed to supply utility green pricing programs offered in Colorado. In 1998, Platte River Power Authority, a wholesale power supplier of four municipalities in northern Colorado, installed two 600-kW turbines at the Medicine Bow, Wyoming, site to supply a green power pilot program offered by one of its members, Fort Collins Utilities. The success of the program prompted Fort Collins to expand its program and encouraged the other cities served by Platte River to launch similar programs in subsequent years. As a result of the strong consumer demand for green power, Platte River expanded the site two times, once in 1999 and then again in 2000, to bring the total installed capacity to $5.8 \mathrm{MW}$.

\section{Utility Commitments and Green Power Demand}

In 1999, wind energy investment accelerated when PacifiCorp and Eugene Water and Electric Board (EWEB) jointly developed the 41-MW Foote Creek Rim project. The utilities were motivated, in part, to include cleaner energy resources in their generation portfolios. The project output has also been used, in part, to meet demand for green power in the Pacific Northwest. PacifiCorp owns about 33 MW of the 41-MW Foote Creek Rim I project, of which almost 20 MW is included in its base rates. PacifiCorp uses $3 \mathrm{MW}$ of the project to supply its Blue Sky green pricing program and markets the remaining $10 \mathrm{MW}$ as green power at wholesale. ${ }^{56}$ For example, the Los Angeles Department of Water and Power has purchased Foote Creek wind power from PacifiCorp for its Green Power for a GreenLA program. EWEB owns the remaining $8 \mathrm{MW}$ of the Foote Creek Rim I project and uses a portion to supply its Windpower green pricing program. The rest of the capacity is supported by all of EWEB's ratepayers. In addition to its voluntary green pricing program, EWEB has set a goal of acquiring new renewable energy capacity equivalent to $1 \%$ of its total load each year. To meet its goal, EWEB has also contracted with the Bonneville Power Administration (BPA) for about 7 MW of capacity from a later phase of the Foote Creek Rim project. ${ }^{57}$

The Foote Creek Rim project has been expanded three times and now totals about $85 \mathrm{MW}$. BPA purchases the output of phase II (1.8 MW) and, until recently, also purchased the output of phase IV (16.8 MW). In conjunction with the nonprofit Bonneville Environmental Foundation (BEF), BPA has marketed at least a portion of the output of these projects as green power to utilities and retail customers in the Pacific Northwest.

\section{Integrated Resource Planning and Settlement Agreements}

Wind energy development in Wyoming has also been spurred by requirements placed on utilities as part of integrated resource planning or merger settlement agreements. Xcel Energy purchases the output of the phase III of the Foote Creek Rim project (25 MW) as a requirement of its 1996 Integrated Resource Planning process. ${ }^{58}$ And PacifiCorp purchases the output of the 50-MW Rock River I wind project in Arlington, to meet a requirement of its merger settlement with ScottishPower in 1999. Under the settlement agreement, the utility committed to install $50 \mathrm{MW}$ of new renewable resources by 2004. By entering into a power purchase agreement for the Rock

\footnotetext{
${ }^{56}$ PacifiCorp Web site http://www.pacificorp.com/Navigation/Navigation551.html, accessed January 9, 2003.

${ }^{57}$ Northway, M; EWEB, personal communication, August 21, 2002.

${ }^{58}$ See Colorado Public Utility Commission, Decision No. C98-1042, adopted October 2, 1998, requiring Xcel Energy to procure $25 \mathrm{MW}$ of wind energy as part of its integrated resource plan.

www.dora.state.co.us/puc/decisions/ 1998/C98-1042_97A-297E.doc, accessed February 24, 2003.
} 
River project in 2001, PacifiCorp fulfilled its commitment three years early. The utility includes the wind power as part of the generation mix that serves its regulated customers. ${ }^{59}$

\section{Future Development}

There is little future development planned for Wyoming due partly to transmission constraints. As there are no state policy incentives available for wind in Wyoming, any future development will need to be driven by demand from surrounding states, which has been the case so far.

\section{Colorado}

Currently, Colorado has about $60 \mathrm{MW}$ (see Table 9) of operational wind energy capacity with another $162 \mathrm{MW}$ planned. The success of early utility green pricing programs has enabled wind energy development to steadily expand in recent years. Through the implementation of these voluntary green power programs, the utilities, the public utilities commission, and regional stakeholders gained experience with wind energy generation, setting the stage for the selection of a large-scale commercial wind energy project through the integrated resource planning process. Favorable economics, resulting in part from recent increases in natural gas prices and uncertainties about future prices, also played a significant roll in advancing wind energy investments. Although renewable portfolio standard bills were introduced in the past two legislative sessions, there are no other state policies or incentives currently in place to support wind energy development in Colorado.

TABLE 9: COLORADO INSTALLED WIND ENERGY CAPACITY

\begin{tabular}{|l|c|c|l|}
\hline \multicolumn{1}{|c|}{ Project } & Size in MW & Date Installed & \multicolumn{1}{c|}{ Power Purchaser } \\
\hline Ponnequin (EIU) (Phase I) & 5.1 & 1999 & PSCo \\
\hline Ponnequin (PSCo) & 16.5 & 1999 & PSCo \\
\hline Ponnequin (Phase III) & 9.9 & 2001 & New Century (Xcel) \\
\hline Peetz Table Wind Farm & 29.7 & 2001 & New Century (Xcel) \\
\hline Total & 61.2 & & \\
\hline
\end{tabular}

\section{Green Pricing}

Consumer demand for green energy drove development of the first few wind projects in the state. One of the earliest green pricing programs was offered by Xcel Energy, which at the time was known as Public Service Company of Colorado. The utility launched its Windsource green pricing program in 1997 and began installing the first $20 \mathrm{MW}$ of capacity at the Ponnequin wind farm to supply the program in 1998. Strong demand prompted the company to expand the program by adding another $10 \mathrm{MW}$ of capacity to the Ponnequin site and another $30 \mathrm{MW}$ at a new facility in Peetz in 2001. Consistent with the national boom-and-bust cycle of wind development in the United States, the two major phases of the wind energy development were timed to take advantage of the federal production tax credit before its expiration in 1999 and again in 2001. Collectively, the utility has installed 77 wind turbines in Colorado to serve its more than 23,000 Windsource customers. Xcel also supplies wholesale wind power to four Colorado utilities, including Holy Cross Energy and Colorado Springs Utilities, who use the power to serve customers who participate in their green pricing programs.

In addition to the green pricing programs supplied by the Peetz and Ponnequin wind sites, there are about 15 green pricing programs offered by municipal and cooperative utilities in Colorado. To date, these programs have not contributed to in-state wind power development, as they are

\footnotetext{
${ }^{59}$ See PacifiCorp's Web site for additional details. http://www.pacificorp.com/Navigation/Navigation551.html, accessed February 24, 2003.
} 
supplied from Wyoming-based wind projects or other renewable energy sources, such as landfill gas.

\section{Integrated Resource Planning and Future Development}

In addition to the capacity installed to serve green power customers, another 108, 1.5 MW wind turbines are under development in southeastern Colorado, driven primarily by economics. The 162-MW Lamar project was approved as part of Xcel Energy's 1999 integrated resource plan, along with another $1,672 \mathrm{MW}$ of capacity additions. ${ }^{60} \mathrm{In}$ its ruling, the Colorado Public Utilities Commission (PUC) found that the proposed wind project was a "cost-effective bid" and directed Xcel to add the project to its resource portfolio. The commission determined that the wind project would cost less than new natural gas-fired generation assuming future natural gas costs of more than $\$ 3.50 / \mathrm{Mcf}^{61}$ In its decision, the commission ordered Xcel to undertake good-faith negotiations with the developer of the proposed Lamar project. Despite some setbacks related to the bankruptcy of Enron, which was the original developer of the project, the negotiations have proved successful. GE is now developing the project and it is expected to be operational by the end of 2003.

\section{Kansas}

Kansas currently has 114 MW of installed wind energy generating capacity, with all but 2 megawatts located at the Gray County Wind Farm in southwest Kansas. Economics is the primary factor driving wind energy development due largely to the state's robust wind resource. Kansas' wind resource ranks third in the nation behind North Dakota and Texas. Kansas also has a full property tax exemption for renewable energy facilities, which further reduces the cost of wind generation. With the combination of strong winds, the federal production tax credit, and the state property tax exemption, the Gray County project is producing power for less than $\$ 0.03$ per $\mathrm{kWh}{ }^{62}$ In addition, the project is supported through the sale of certificates that are used to meet consumer demand for green energy.

\section{Property Tax}

Under a law that took effect in January 1999, Kansas exempts wind energy facilities from all property taxes. Normally, utility property (which includes wind turbines) assessed for property tax purposes must be assessed at 33 percent of the project's total value. ${ }^{63}$ The savings from the full property tax exemption are considerable. For example, a wind generation facility with a total value of $\$ 100$ million similar to the one in Gray County would have been subject to more than $\$ 4.7$ million in local property tax in $2002 .^{64}$ The amount of property tax would, of course, diminish in future years as the value of the property depreciates. Although the Gray County facility was exempt from property taxes, the developer decided to pay approximately $\$ 330,000$ annually to the county where the project is located. According to the Kansas Corporation Commission (KCC), this $\$ 330,000$ payment is congruent with the amount of property tax a

\footnotetext{
${ }^{60}$ Colorado Public Utilities Commission, news release, "PUC Approves Xcel Resource Plan with Addition of Wind Project," February 23, 2001.

${ }^{61}$ Lehr, R.L., J. Nielsen, S. Andrews, and M. Milligan; “Colorado Public Utility Commission's Xcel Wind Decision.” Paper presented at AWEA Windpower 2001 Conference, Washington, D.C., June 4-7, 2001. NREL/CP500-30551, September 2001.

${ }^{62}$ Sloan, T; Kansas State Representative, personal communication, April 14, 2003.

${ }^{63}$ Denney, J; Kansas Appraisers Office telephone communication, April 30, 2003. See the Constitution of the State of Kansas, Article 11, Subsection 1 titled "System of taxation; classification; exemption."

${ }^{64}$ Plotner, S.; Gray County Treasurer, personal communication, April 11, 2003. Without the property tax exemption, a $\$ 100$ million wind farm would have an assessed value of $\$ 33$ million in Kansas. In Gray County, this value would have been subject to a mill levy of .144712 for 2002 . $\$ 33$ million x .144712 $=\$ 4,775,496$.
} 
similar size wind farm would generate annually in other states like North Dakota and Minnesota where various property tax incentives exist for wind power. ${ }^{65}$

\section{Green Power Markets}

The 110-MW Gray County wind farm is also partly supported through wholesale sales of green energy certificates. In fact, Aquila, the utility that purchases the output of the facility, reports that it has already sold to a retail green power marketer all of the attributes associated with the 2003 energy output. The retail marketer uses the attributes to meet consumer demand for green energy in the region or nationally. According to a representative of Aquila, the ability to sell renewable energy certificates did not influence its decision to enter into the wind power purchase contract because the value of attributes was uncertain at the time. Aquila's primary motivation for investing in wind power was because it was cost-competitive. Today, however, the ability to sell the attributes would play a larger role in the utility's decision. ${ }^{66}$

\section{Transmission}

In the future, wind energy developers may benefit from two transmission-related bills adopted by the state legislature in 2003. Although the new laws are not specific to wind, they are beneficial to wind and other power technologies. HB 2018 permits the Kansas Development Finance Authority (the same agency that markets state highway bonds) to market bonds on behalf of utilities to help build or upgrade transmission lines. Another bill, HB 2130, authorized the KCC to consider FERC decisions on transmission line issues; but, most importantly, it permits the $\mathrm{KCC}$ to consider regional transmission needs in permitting transmission projects in Kansas.

\section{Future Development}

Favorable economics and the property tax incentive may continue to drive future wind energy development in Kansas. Transmission issues could restrict development opportunities, but new laws facilitating transmission upgrades may help alleviate potential problems. In the short term, at least one wind project is expected to move forward. Renewable Energy Systems plans to construct a wind farm in Western Kansas by the end of 2003, which could ultimately grow to 100 MW. Sunflower Electric Power Corporation, a wholesale power supplier for six rural electric cooperatives, has agreed to buy the first $30 \mathrm{MW} .^{67}$

\section{Pennsylvania}

Although Pennsylvania has a modest wind resource, about 35 MW (see Table 10) of wind energy was installed in 2002 and another $60 \mathrm{MW}$ to $110 \mathrm{MW}$ is expected in 2003. Wind power development has been spurred by a combination of consumer demand for wind power, particularly among businesses and institutional customers, financial incentives available through the state's system benefits funds, and the promise of future markets for renewables in meeting regional RPS requirements. Contributing to the success of the consumer market for green power have been market rules that, at least initially, favored competition; relatively high standard-offer rates in the initial stages of retail competition that have encouraged consumers to switch suppliers; rules that are favorable to wind generators; and the willingness on the part of a large utility to commit to assuming some of the development risk by entering into long-term wind power purchase contracts. The state's renewable energy funds, which were created as part of electric industry restructuring, have also facilitated wind energy development by providing financial incentives such as production incentives, debt financing, and grants to reduce wind

\footnotetext{
${ }^{65}$ Ploger, J.; Kansas Corporation Commission, personal communication, April 9, 2003.

${ }^{66}$ Veatch, R.; Aquila Networks, e-mail correspondence, April 24, 2003.

${ }^{67}$ News release, "Sunflower Electric Wind Farm to Be Built in Western Kansas," February 4, 2003
} 
energy costs. Further, the promise of future markets for wind power created by renewable portfolio standards in the region, particularly in New Jersey, has also encouraged development. The early success of the Pennsylvania wind market has been instrumental in encouraging wind energy development throughout the region, particularly in neighboring states, such as New York and West Virginia.

TABLE 10: PENNSYLVANIA INSTALLED WIND ENERGY CAPACITY

\begin{tabular}{|l|c|c|l|}
\hline \multicolumn{1}{|c|}{ Project } & Size in MW & Date Installed & \multicolumn{1}{c|}{ Power Purchaser } \\
\hline Humboldt Industrial Park & 0.1 & 1999 & N/A \\
\hline Garrett (Somerset County) & 10.4 & 2000 & Green Mountain Energy \\
\hline Mill Run Windpower & 15.0 & 2001 & Exelon Power Team \\
\hline Somerset & 9.0 & 2001 & Exelon Power Team \\
\hline Total & 34.5 & & \\
\hline
\end{tabular}

\section{Green Power Demand}

Customer demand for wind power, particularly on the part of businesses, drove the development of the first commercial-scale wind turbines in Pennsylvania. In 1999, two 65-kW wind turbines were developed at Humboldt Industrial Park southwest of Hazleton by a newly formed green power marketer, Community Energy, and a local developer, Energy Unlimited. The output of the turbines was marketed as "Pennsylvania Wind Energy" in 400 kilowatt-hour monthly blocks to business customers. Some businesses were able to purchase the wind energy blocks for a portion of their electric use and still, in aggregate, pay less overall than the current utility rate because of the high standard offer rates in the Philadelphia area, and the consequent ability to save money by switching to a competitive provider. Shortly after the construction of the small wind plant, Community Energy announced that the entire output had been sold to more than 25

Pennsylvania-based businesses. ${ }^{68}$ The Hazelton project was also able to move forward because it received \$250,000 in subordinated debt financing from the PECO Sustainable Development Fund (SDF), which was created in the 1998 PECO restructuring settlement and expanded in the Unicom-PECO merger order. ${ }^{69}$

Residential consumers also supported development of wind energy in the state. In 2000, green power marketer, Green Mountain Energy (formerly GreenMountain.com) and American National Wind Power developed a 10.4-MW wind farm in Garrett, Pennsylvania, to serve Green Mountain's base of more than 60,000 Pennsylvania-based green power customers at the time. ${ }^{70}$ Although many of its customers use the electricity for their households, Green Mountain also contracted with a number of large, nonresidential customers including the state of Pennsylvania. High standard-offer prices in the PECO service territory enabled Green Mountain to compete against the incumbent utility and enabled them to offer products at modest price premiums. In fact, Green Mountain initially offered a product supplied in part from renewable sources at less than the standard-offer rate.

\footnotetext{
${ }^{68}$ Community Energy news release, "Blowin' in the Wind: New Wind Electrifies Pennsylvania," December 31, 1999. http://www.cleanair.org/press/pawindenergy2.html

${ }^{69}$ There are four state funds available to support renewables and energy efficiency in the following utility service territories: PECO (lump sum of \$13.5 million through 2006), PP\&L (about \$3.5 million annually through 2004), MetEd and Penelec (combined lump sum of \$12.1 million through 2004), and West Penn/Allegheny Power (lump sum of \$11.4 million through 2005). Also, another \$18.5 million, including \$12 million designated for wind energy, was added to the PECO fund, as a result of the PECO Energy and Unicom merger settlement agreement. After the dates indicated, funding is to continue based on a surcharge of $0.005-0.01 \notin / \mathrm{kWh}$ added to customers' electricity bills. (Bolinger, et al., 2001)

${ }^{70}$ GreenMountain.com news release, "GreenMountain.com Announces Ground Broken on Green Mountain Wind Farm,” December 1, 1999. http://www.eere.energy.gov/greenpower/gmtn 699a pr.html
} 
The momentum of the green power market was a sizable contributor to another $25 \mathrm{MW}$ of capacity to come on-line in 2001. The 15-MW Mill Run project and the 9-MW Somerset projects were developed as a result of a five-year cooperative marketing agreement between Exelon Power Team, a subsidiary of PECO Energy, and Community Energy. Under the agreement, Exelon Power Team signed long-term power purchase contracts (20 years) for the wind energy output, while Community Energy committed to market the power to business and residential customers in the region. Exelon Power Team originally envisioned that the wind power would be sold to retail customers and retail aggregators in the competitive market, as well as to distribution companies (such as PECO) that planned to offer wind energy options to customers on standardoffer service. $^{71}$ As it has turned out, most of the wind energy output to date has been sold to nonresidential customers in Pennsylvania, including a number of universities, state agencies, and businesses, at a premium of about $2 \notin / \mathrm{kWh}$.

\section{System Benefits Funds}

Incentives available through the state's system benefits funds facilitated the development of the Mill Run and Somerset wind energy projects. The PECO SDF provided production incentives of $1.5 \phi / \mathrm{kWh}$, capped at a combined total of $\$ 2$ million. In addition, the SDF and several other state system benefits funds conditionally approved a $\$ 3.6$ million loan to provide secured debt financing for the Somerset project. Although the financing was withdrawn in 2002 because the project changed hands and the debt financing was no longer needed, the SDF reported that "[it] is clear that without our early support of the Somerset Windpower project through the conditional approval of subordinated debt financing, the project would not have obtained a financible long-term power purchase agreement and would not have been built."72 According to one estimate, the subordinated debt financing would have reduced the power purchase price by $0.6 \notin / \mathrm{kWh}$, providing an incentive similar to a $\$ 1$ million grant. ${ }^{73}$

The state's system benefits funds have also encouraged green power marketing activity by providing grants and other financial incentives to green power marketers. For example, the PECO fund provided grants to marketers and nonprofits to develop business plans for marketing renewable energy products and educating customers about clean energy options. At least one marketer also received loans and equity financing from some of the renewable energy funds.

\section{RPS Markets}

The New Jersey renewables portfolio standard has also played a role in encouraging wind energy development in Pennsylvania and the broader region by providing an alternative market for the output of wind projects in the longer term. Under the New Jersey standard, Class I technologies (which include wind power) must be used to meet $0.5 \%$ of retail electricity loads by 2001 , increasing to $1 \%$ of retail electricity loads by 2006 , and then increasing $0.5 \%$ annually to $4 \%$ by 2012. In the near term, lower-cost existing renewable energy sources in the region, such as landfill gas, are expected to be sufficient to meet the New Jersey RPS. In the longer term, as the standard increases, existing landfill gas resources may be exhausted and the RPS may begin to support existing and new wind development; however, this is unlikely to occur much before 2010. In April 2003, a renewable energy task force formed by New Jersey's governor

\footnotetext{
${ }^{71}$ Freeman, M.; Exelon Power Team, personal communication, April 8, 2003.

${ }^{72}$ Sanders, R. and R. Clark; Semi-Annual Report to the Pennsylvania Public Utility Commission and to the Joint Petitioners: July 1, 2002-December 31, 2002, Sustainable Development Fund of PECO Service Territory January 31, 2003. http://www.trfund.com/sdf/pdf docs/PUC_Report 8.doc

${ }_{73}^{73}$ Bolinger, M.; Case Studies of State Support for Renewable Energy: Use of Low-Interest, Subordinated Debt to Finance a Wind Project in Pennsylvania, Lawrence Berkeley National Laboratory, September 2002. http://eetd.lbl.gov/ea/EMS/cases/Subordinated_Debt.pdf
} 
recommended strengthening the state's RPS requirement. If the recommendations are adopted, new renewable energy capacity may be needed to meet the revised standard by about 2007, which could provide enhanced opportunities for wind. There are also modest renewable energy requirements in the Pennsylvania utility service territories, but these are also likely to be met with lower-cost renewable generation sources, such as landfill methane. ${ }^{74}$ If adopted, RPS policies considered in surrounding states such as Maryland and Pennsylvania also could influence future development.

\section{Market Rules}

Wind energy projects have also been able to move forward in the PJM ISO because scheduling and wholesale market rules are favorable to intermittent resources. For example, the PJM market operates without penalties for schedule deviations, which reduces the costs of selling wind energy output into the wholesale market. ${ }^{75}$ In addition, PJM offers real time scheduling and is a relatively liquid spot market with a significant volume of power purchases and sales that provides a viable wholesale market for wind energy generators. Recently, PJM announced its intention to give wind energy capacity credit.

\section{Future Development}

Pennsylvania's system benefits funds, particularly the PECO fund, are expected to continue providing financial support to encourage wind energy development in the near future. Recently, the PECO SDF negotiated $\$ 10$ million of wind production incentives with four Pennsylvania wind project developers representing 146.5 MW of additional wind power capacity. Draft agreements were sent to the four developers in December 2002 and the parties are now finalizing these agreements. ${ }^{76}$ One or more of these projects are likely to be completed by the end of 2003. Some of the other system benefits funds are also actively considering loans for wind project developers.

\section{West Virginia}

While only one wind project is operational to date, West Virginia has $66 \mathrm{MW}$ of wind energy capacity, and hundreds of additional megawatts have been proposed. The drivers for wind energy development in West Virginia are similar to those for Pennsylvania, namely to meet consumer demand for green power and to supply regional RPS markets in the future. West Virginia is one of the closest wind resource areas to Washington, D.C., which positions it to serve green power demand by D.C.-based customers. Another key factor is that wind energy generation costs in West Virginia are relatively low compared to other areas of the region, reportedly slightly under 4 cents/kWh, due in part to a relatively strong wind resource, the ability to site sizable projects, and market rules that are favorable to wind in the PJM. Also important was the state's ability to address punitive state tax policies to level the playing field for wind generators. As with Pennsylvania, another important element that has contributed to wind energy investment is a

\footnotetext{
${ }^{74}$ For PECO, West Penn, and PP\&L, 20\% of residential consumers must be served by a competitive default provider with $2 \%$ of the electricity coming from renewables in 2001, increasing $0.5 \%$ annually thereafter. For the GPU service territory, $20 \%$ of residential consumers must be served by a competitive default provider with $0.2 \%$ of the electricity coming from renewables in 2001 . The fraction of customers served by a competitive default supplier is to increase to $40 \%$ in $2002,60 \%$ in 2003 , and $80 \%$ in 2004 and thereafter. However, implementation of these requirements has not occurred consistently.

${ }^{75}$ Ellison, C., L. Haug, and A. Brown.; A Review and Update Regarding the 2000 AWEA Transmission Access Priority Issues Report. Prepared for the American Wind Energy Association by Ellison, Schneider \& Harris, LLP, December 2002.

${ }^{76}$ Sanders and Clark, 2003
} 
partnership between a large utility and a green power marketer, in which the utility assumed much of the risk by entering into a long-term contract for the wind energy output.

\section{Green Power Demand}

The first utility-scale wind energy project in West Virginia was developed primarily to meet demand for green power in the region. As they have done in Pennsylvania, Exelon Power Team entered into a long-term, 20-year contract for the output of the 66-MW Mountaineer Wind Energy Center and teamed with Community Energy to market the output of the project in the region. In order to serve customers in the Washington, D.C., area, Community Energy also teamed with another marketer, Washington Gas Energy Services (WGES). Shortly after the turbines were installed in December 2002, WGES and Community Energy announced that about $25 \%$ of the facility's output was under contract to regional end-users, including about 5,000 residential and small commercial customers, and a number of large nonresidential customers, such as the U.S. Army, Catholic University, and National Geographic. ${ }^{77}$

\section{Regional RPS Policies}

As discussed earlier, the New Jersey RPS provides an alternative market for the output of wind projects in the PJM in the future. Other lower-cost renewables, such as landfill gas, are expected to sufficiently meet the N.J. RPS in the near term; but as the requirement becomes increasingly stringent over time, utilities may need to acquire additional power from other renewable energy projects by about 2010. If the recommendations made by the New Jersey governor's task force are adopted, new renewable energy capacity may be needed to meet the revised standard by about 2007, which could provide enhanced opportunities for wind. Also, RPS policies under consideration in surrounding states such as Maryland and Pennsylvania could influence future development.

\section{State Tax Parity}

The Mountaineer project was able to move forward partly because the West Virginia Legislature made important adjustments to two tax laws in 2001 that level the playing field for wind energy developers. Prior to these adjustments, wind energy generators would have had to pay approximately three to four times the amount of tax on a per kilowatt-hour basis compared to coal generators. In order to address this discrepancy, the state legislature reduced the business and operation tax affecting utilities that use wind power as part of their generation mix. The tax is now based on $5 \%$ of a project's production capacity, rather than the previous $40 \%$. During the same session, the legislature also reduced the property tax for wind power projects by basing the tax on $5 \%$ of a project's assessed value rather than $100 \% .{ }^{78}$ Without these changes to the state's tax policy, the Mountaineer Wind Energy Center likely would not have been completed. ${ }^{79}$

\section{Market Rules}

As noted earlier, scheduling and market rules in PJM are nondiscriminatory to intermittent resources, and therefore encourage wind development. For example, the PJM market operates without penalties for schedule deviations, which reduces the costs of selling wind energy output into the wholesale market. ${ }^{80}$ In addition, PJM offers real time scheduling and is a relatively liquid spot market with a significant volume of power purchases and sales that provides a viable

\footnotetext{
77 Washington Gas Energy Services news release, "Leading D.C. Area Institutions Announce Wind Energy Purchases from Newly Operating 44 Wind Turbines," January 30, 2003. http://www.wges.com/press.htm?p=2 ${ }^{78}$ AWEA, 2002.

${ }^{79}$ DeWolf, T.; Atlantic Renewable Energy Corp., personal communication, April 11, 2003.

${ }^{80}$ Ellison, Haug, and Brown 2002.
} 
wholesale market for wind energy output. Recently, PJM announced its intention to give wind energy capacity credit.

\section{Future Development}

With respect to future development, a number of wind projects totaling upward of $600 \mathrm{MW}$ have been proposed. However, there is considerable uncertainty surrounding the probability of completion of a number of these projects, due in part to the uncertainty surrounding the extension of the federal production tax credits and potential RPS policies in the region. A 150MW project planned for Mount Storm in Grant County may move forward in the short term, which would essentially triple the current installed capacity if completed. However, local opposition and siting issues have begun to emerge, which may make it more difficult to develop proposed and future projects. Also development will depend largely on policies and markets for wind in other states, as West Virginia currently does not provide any incentives for wind energy.

\section{New York}

New York currently has 49 MW (see Table 11) of installed wind energy capacity, all of which has been installed since 2000. The three existing large-scale projects have been able to move forward largely through the availability of incentives from the state's systems benefits fund. Consumer demand for green power is also providing some support. Another factor that has influenced wind energy development is that the state has wholesale market and interconnection rules that allow wind to compete with traditional fuels. Future development may be driven by an RPS, which is currently under development; however, any large-scale expansion may be hindered by transmission constraints.

TABLE 11: NEW YORK INSTALLED WIND ENERGY CAPACITY

\begin{tabular}{|l|c|c|l|}
\hline \multicolumn{1}{|c|}{ Project } & Size in MW & Date Installed & \multicolumn{1}{|c|}{ Power Purchaser } \\
\hline Madison Windpower & 11.6 & 2000 & Merchant plant \\
\hline Wethersfield, Wyoming County & 6.6 & 2000 & Niagara Mohawk \\
\hline Fenner Wind Power Project & 30.0 & 2001 & NY Power Pool \\
\hline Total & $48.5^{*}$ & & \\
\hline *Includes projects under 1 MW not listed. \\
\hline
\end{tabular}

\section{System Benefits Fund}

New York has a system benefits fund that has been used in part to promote wind energy development. Created in 1996 as part of electric industry restructuring, the fund was designed to support energy efficiency, low-income assistance, and renewable energy. Renewables are supported through the portion allocated for research and development (R\&D). The fund received $\$ 234.3$ million for the first three years from July 1998 through June 2001; of this, approximately $\$ 40$ million was allocated for R\&D projects that included wind power development. In 2001, the PSC extended the system benefits charge through June 2006 and increased its budget to $\$ 150$ million per year, of which R\&D is expected to receive \$208 million through 2006. The New York State Energy Research and Development Authority (NYSERDA) administers the funds. ${ }^{81}$

To date, the system benefits fund has been used in a variety of ways to lay the groundwork for wind development, such as identifying potential sites, creating wind resource maps, and providing incentives for green power marketers. Grants and incentives have also been used to reduce the cost of about $49 \mathrm{MW}$ of wind generation to date. For example, NYSERDA provided a $\$ 4$ million grant to the 6.6 MW Weathersfield project in Wyoming County and a total of about

\footnotetext{
${ }^{81}$ Database of State Incentives for Renewable Energy, accessed March 28, 2003. www.dsireusa.org
} 
$\$ 7$ million in financial incentives to the $11.5 \mathrm{MW}$ Madison wind project and the $30 \mathrm{MW}$ Fenner project in the form of an up-front grant $(25 \%)$ and a series of availability-based payments over three years. These incentives translated to about $1.77 \phi / \mathrm{kWh}$ over five years on a levelized basis. ${ }^{82}$ In addition, NYSERDA has awarded production incentives to more than $300 \mathrm{MW}$ of additional wind capacity that has not yet come on-line.

\section{Green Marketing}

New York's three large-scale wind projects (totaling $49 \mathrm{MW}$ ) are also supported in part through green power marketing. Since late 2002, a number of retail green power marketers have entered the state. For example, four companies - Community Energy, Green Mountain Energy, the Energy Cooperative of New York, and Sterling Planet - are marketing green power to customers through a collaborative program with Niagara Mohawk, which stems from the settlement agreement reached in the utility's merger with National Grid. Green Mountain recently announced that it purchased all of the attributes of the Madison project to supply its green energy customers in the Niagara Mohawk service territory. Community Energy has also teamed with NYSEG to provide a green power option to the utility's customers in upstate New York. And the company has an agreement with ConEdison Solutions to market green energy to customers in New York City. Community Energy supplies these products with output from the Fenner and Weathersfield projects.

A commitment on the part of the state of New York to purchase renewable energy for state buildings has boosted demand for green energy. In June 2001, Governor George Pataki issued an executive order declaring that at least 10 percent of the total energy used in buildings that the state owns, leases, or operates must be from renewable resources by 2005 . The order increases the amount to 20 percent by 2010 .

\section{Market and Interconnection Rules}

In the past four to five years, the NYISO has structured the state's wholesale power market rules to make them more favorable to wind power. Wind power is often penalized in power markets because it is an intermittent resource; however, the NYISO has developed rules to accommodate wind so that it can compete with traditional power sources. One way NYISO has done this is to give wind power partial capacity payments equivalent to the project's capacity factor. ${ }^{83}$ In addition, NYISO has interconnection rules that exempt the first $500 \mathrm{MW}$ of intermittent generation from imbalance penalties for schedule deviations. Furthermore, the ISO streamlined the approvals process that wind projects must go through by decreasing the amount of time and studies required to approve wind projects. These changes level the playing field for wind generation and lower costs.

\section{Future Development}

In New York, incentives available through the system benefits fund and an RPS that is under development are expected to drive future development. System benefits funds have been awarded to more than $300 \mathrm{MW}$ of additional wind capacity that has not yet come on-line. In addition, Governor Pataki recently called on the Public Service Commission to implement an RPS that would require 25 percent of the state's power to come from renewable sources, including hydroelectric, by 2012. New York currently gets approximately 18 percent of its

\footnotetext{
${ }^{82}$ Bolinger and Wiser 2002.

${ }^{83}$ Porter, K.; Exeter Associates, personal communication, June 29, 2003.
} 
power from renewable sources, nearly all of which comes from hydroelectric power. ${ }^{84}$ The PSC has initiated a collaborative process to examine key issues regarding the structure and implementation of the RPS. Once the rules are finalized, this is expected to be an important driver for wind energy development over the long term. The green power market may also continue to grow and to support new wind development. A number of retail marketers entered New York in 2002; and, as these early programs develop, they may create a need for new resources, particularly in light of the state's commitment to purchase renewable energy for its facilities.

\section{SUMMARY OF LESSONS FROM THE LEADING STATES}

This paper describes the factors that spur wind development in leading U.S. states. It has two fundamental messages:

(1) State tax and financial incentives, as well as state renewable portfolio standards, can and do have an important effect on wind energy development. This impact is most pronounced when wind generation is already nearly competitive with more traditional generation resources (e.g., gas-fired generation), for example, in states with particularly strong wind resources.

(2) The increasingly lower cost of wind generated electricity - due in part to a movement toward larger, more efficient turbines, and facilitated by federal tax incentives - is now an important driver for new wind installations. Simply said, there are some regions of the United States in which wind power is the lower-cost resource option.

Any state policy to encourage or mandate wind development functions in the context of other powerful drivers: the quality of the wind resource, the cost of conventional generation in the region, the need for new electricity supplies, the willingness of power companies to integrate wind into their systems, the ease of siting and permitting wind facilities, the quality of the power delivery system, and the rules that govern the transmission system. The wind resource and the capacity of the transmission system to integrate wind generation are probably the most important of these contextual elements.

The quality of the wind resource determines, in large part, the cost of producing electricity from wind power. In states with high-quality wind resources, relatively modest financial incentives may be effective in driving significant wind development, in the absence of other constraints. Likewise, wind developers would need large incentives in states with poor wind resources in order to be economically competitive with other resources. Thus, the wind resource may determine the magnitude of the policy incentives needed. However, the existence of strong wind resource and policy incentives may not be sufficient to stimulate investment if other barriers exist, such as transmission constraints.

Large wind farms depend on the transmission system to deliver power from the sometimesremote locations in which wind resources are strongest, to the markets that need the electricity. Transmission is important because some of the highest-quality wind resources are in parts of the country such as Montana, North and South Dakota, rural Midwestern states, or west Texas; while the cities that need the power are far from the windy areas. The transmission system in the United States, overall, has become more heavily loaded and constrained because load has continued to grow and few significant line upgrades or additions have occurred in the past

\footnotetext{
${ }^{84}$ Energy Information Administration (EIA), accessed May 1, 2003. http://www.eia.doe.gov/cneaf/electricity/st profiles/new york/ny.html\#t5
} 
decade or more. Investments in new transmission are costly, difficult to site and permit, and restricted by the uncertainties of the market given evolving FERC rules. Further, current rules and capacity ratings for existing transmission lines can be problematic for wind generators. For example, rules requiring capacity-based payment for access to transmission place a greater financial burden on wind. A full discussion of transmission issues is beyond the scope of this paper. However, transmission accessibility is a very important consideration to wind developers; and, along with the influence of the wind resource, can overwhelm the influence of most state incentives and other drivers for wind development.

The siting process can also be very important. Siting laws and regulations dictate the process that any new project must pass through in order to obtain a permit to build a new wind facility. As an example, laws in some states prohibit building certain structures on ridgelines. Even where laws do not explicitly prohibit building in certain areas, the political or social environment may be unfriendly to development of wind energy facilities. Most power project developers, for instance, view Texas as a hospitable climate for building new energy facilities, including wind plants.

Within the broad context of wind resources, transmission availability, federal policies, and other considerations, incentives and other state policies are important and can in many cases be instrumental in making some wind projects economic. Table 12 provides a summary and comparison of wind energy development, resource potential, and policy incentives available in the states that we have examined in this paper. Based on the experience of these states, we discuss the key policy and market drivers for wind energy development below.

\section{Renewable portfolio standards}

Renewable portfolio standards or purchase mandates are the most powerful tool that a state can use to promote wind energy. So far, these have been particularly important for driving wind energy investment in Texas, Minnesota, and Iowa, where more than 1,700 MW of new capacity has been developed to meet the requirements of just these three states. Some success has also been generated with such policies in Wisconsin, New Jersey, and Nevada. The success of the Texas RPS is credited to a variety of factors including strong implementation support from the public utilities commission, a credit-trading system that increases compliance flexibility, and penalties for noncompliance. Not all renewable portfolio standards are equally effective; details in design and implementation make a big difference.

Some portfolio standards have been directly responsible for wind development, not only in the states in which they have been enacted, but also in neighboring states. For example, wind energy capacity has been constructed in Iowa to meet the Wisconsin RPS, and projects have moved forward in Pennsylvania and West Virginia with an eye toward eventually being used to meet the New Jersey RPS. State RPS policies are expected to play a leading role in stimulating wind energy development in the future. The recently adopted California RPS, which requires $20 \%$ non-hydro renewables by 2017 , is one of the most aggressive in the nation, ultimately requiring on the order of 2,900 average MW of new renewable energy generation. New York is also early in the process of developing rules for an RPS that could require utilities to obtain $25 \%$ of their portfolio from renewable sources by 2013. 
TABLE 12: COMPARISON OF STATE WIND CAPACITY, RESOURCE POTENTIAL, AND INCENTIVES

\begin{tabular}{|c|c|c|c|c|c|c|}
\hline & State & $\begin{array}{l}\text { Cumulative } \\
\text { Installed } \\
\text { Capacity } \\
(\mathrm{MW}, 2002)\end{array}$ & $\begin{array}{l}\text { Resourc } \\
\text { e Rank }\end{array}$ & RPS/ Mandate & $\begin{array}{l}\text { Retail } \\
\text { Green } \\
\text { Power } \\
\text { Products }\end{array}$ & Financial Incentives \\
\hline 1 & CA & 1822 & 17 & $20 \%$ by 2017 & $6 * *$ & System benefits charge (SBC) \\
\hline 2 & TX & 1096 & 2 & $\begin{array}{l}2000 \text { MW by } \\
2009\end{array}$ & $4 * *$ & $\begin{array}{l}\text { Property tax, franchise tax } \\
\text { exemption }\end{array}$ \\
\hline 3 & IA & 423 & 10 & $105 \mathrm{aMW}$ & 8 & Property tax, sales tax, loan fund \\
\hline 4 & $\mathrm{MN}$ & 336 & 9 & $\begin{array}{l}425 \text { MW by } 2002, \\
400 \text { MW by } 2012 ; \\
10 \% \text { by } 2015 \text { goal }\end{array}$ & 63 & $\begin{array}{l}\text { Fund, property tax, production } \\
\text { incentive, accelerated depreciation }\end{array}$ \\
\hline 5 & WA & 228 & $>20$ & -- & $14^{* *}$ & Corporate tax, sales tax incentive \\
\hline 6 & OR & 218 & $>20$ & -- & $10 * *$ & $\begin{array}{l}\text { SBC, business tax credit, property } \\
\text { tax exemption }\end{array}$ \\
\hline 7 & WY & 141 & 7 & -- & $2 * *$ & -- \\
\hline 8 & KS & 114 & 3 & -- & ** & Property tax exemption \\
\hline 9 & WV & 66 & $>20$ & -- & ** & \\
\hline 10 & $\mathrm{CO}$ & 61 & 11 & -- & $20 * *$ & \\
\hline 11 & NY & 49 & 15 & $\begin{array}{l}25 \% \text { by } 2013 \\
\text { planned }\end{array}$ & & SBC \\
\hline 12 & PA & 35 & $>20$ & & & SBC \\
\hline \multicolumn{2}{|c|}{ Total } & 4589 & & & & \\
\hline \multicolumn{7}{|c|}{$\begin{array}{l}{ }^{2} \text { Based on annual energy potential and environmental and land use restrictions for class } 3 \text { or higher wind sites. } \\
\text { Source: Pacific Northwest Laboratory. An Assessment of the Available Windy Land Area and Wind Energy } \\
\text { Potential in the Contiguous United States, } 1991 \text { as cited by AWEA } \\
\text { http://www.awea.org/pubs/factsheets/WEUntappedResource.pdf. }\end{array}$} \\
\hline
\end{tabular}

\section{System benefits funds}

System benefits funds can also promote wind energy development. These funds have proven to be important for stimulating investment in wind energy facilities in states such as Pennsylvania, New York, and California, and may become increasingly important in places like Oregon.

Relative to some other types of policies, system benefits funds offer the advantage of flexibility; they can be used to provide a variety of financial incentives such as debt or equity financing, production incentives, grants, or support for the development of green markets. In some cases, system benefits funds can be most helpful in the early stages of wind development by funding activities such as wind-resource mapping or monitoring to identify promising wind sites, and site preparation. Therefore, they can also be helpful in states with little experience in wind development.

\section{Integrated Resource Planning (IRP)/Settlement Agreements}

The IRP process and settlement agreements resulting from mergers or other activities have driven wind power development in some regions. These are also important avenues for stakeholders and advocates to encourage the further development of wind energy.

IRP is an electric-system planning process that became popular in the late 1980s. IRP requires utilities to forecast demand for power and examine alternative scenarios of resources to meet that demand. The least expensive combination of resources (whether they are wind, natural gas, coal, nuclear, energy efficiency, or other sources) is then chosen to meet the utilities' needs, considering environmental constraints, risks, and other factors. The state utilities commission examines the utility's IRP plan and approves or modifies it. 
With the advent of retail competition in many states, long-time critics of the IRP process declared it irrelevant or anachronistic. Many states that adopted competition simultaneously rejected integrated resource planning.

Yet IRP continues to be a powerful force in some states, and is enjoying resurgence in others where the move toward competition has been delayed or postponed indefinitely. IRP remains an important driver for wind energy. For example, Colorado's utility commission required Xcel Energy to build nearly $200 \mathrm{MW}$ of new wind facilities that were found to be cost-effective as a result of increases in natural gas prices. Treatment of projected natural gas prices is likely to continue to be a key issue for wind in the IRP process. In Oregon, PacifiCorp recently issued an integrated resource plan that calls for the installation of approximately $1,400 \mathrm{MW}$ of new wind projects to meet its projected load growth.

Merger settlement agreements also have presented limited opportunities for wind energy development, and have resulted in new capacity additions or funding to support wind energy in the Pacific Northwest and the Northeast.

\section{Property tax incentives}

Property tax abatements can be one important incentive for wind developers, although they may not (by themselves) be capable of stimulating new wind development, except in areas with particularly good wind resources. One goal of property tax policy may be to place the property tax burdens on wind facilities on par with other generators in the state or on par with wind development in other neighboring states. Property tax abatements can be significant to developers, even when the developer chooses to make a smaller cash payment to the local community in lieu of the property tax. One Kansas wind facility, for example, now makes an annual payment of slightly more than $\$ 300,000$ to the local community; but, if it were paying property taxes, it would have paid more than $\$ 4.5$ million in 2002 alone. Such differences can be very important to a wind developer. Property tax incentives have also been used in Texas, Iowa, Minnesota, and Oregon. One concern regarding the use of property tax exemptions is that they reduce the local economic development benefits that would result from the project, which may be particularly problematic for rural communities where development is likely to occur.

\section{Sales tax incentives}

Sales tax abatements can be important to wind developers because wind facilities are so capital intensive. Again, however, they may not be able to stimulate new wind energy investments by themselves. Sales tax exemptions are a one-time tax benefit that developers realize at the time of equipment purchase. In some circumstances, sales tax payments are lower than property tax payments, so sales tax exemptions may therefore be less important to developers than property tax abatements - while in other states they can be more important. The relative importance of the two depends on the economic value of each incentive. In a state with very good to excellent wind resources and good transmission availability, sales tax abatements may influence a developer's decision to build a wind facility. Both Iowa and Washington offer sales tax exemptions for wind development. One concern regarding the use of sales tax exemptions is that they reduce the state tax revenues that would result from wind projects, which can be problematic for states during tight economies. 


\section{Green Power Markets}

Green markets can provide an important revenue stream to support investment in wind energy facilities. Consumer demand for green power has been a key contributor to the successful development of projects in several Mid-Atlantic states, Colorado, Wyoming, and in the Pacific Northwest, among others. In some instances, such as Colorado and Pennsylvania, green markets have provided utilities, regulators, and advocates the opportunity to gain experience with wind resources, paving the way for further development. Nationally, wind energy projects totaling about $900 \mathrm{MW}$ are being supported, in part, through premiums paid voluntarily by green power customers.

Although green markets may not alone provide enough stable revenue to support large-scale development, they can be used in conjunction with other policy mechanisms to drive substantial amounts of wind power. Wind energy projects have been supported through a combination of systems benefits funds and customer premiums in states such as New York and Pennsylvania. Where RPS policies are in place, green power marketing can enable developers to construct larger and more cost-effective projects, with a portion being used to meet the RPS and a portion

to meet consumer demand. For publicly owned utilities that may not be able to benefit from state tax incentives or other policy supports, green power marketing may be a particularly important form of support for wind development.

\section{Wholesale Market Rules}

Wholesale market rules can also influence wind energy development in a state or in a region. PJM, for example, has encouraged wind energy development by providing a fluid spot market through which generators can sell their output, real-time scheduling, and no penalties for schedule deviations. Recently, PJM announced its intention to give wind energy capacity credit, and allow wind to compete in PJM's capacity markets. Its rules accommodate intermittent resources and therefore have enabled wind projects to move forward in the region. Other states, such as California, have recently changed their wholesale market rules to better accommodate intermittent resources that fail to generate power at particular times. Nondiscriminatory market rules can be particularly important for merchant wind projects that sell their output on the open market.

\section{CONCLUSION}

It is impossible to discern one single driver for wind development; all of the different drivers function as a package and influence one another's effectiveness. It is clear from the tremendous growth in wind development that a combination of policies, vastly improved economics, and a developing market for green power are all having a sizable effect on the wind industry.

Of the various state policy drivers, the renewable portfolio standard appears to be the most effective. But financial incentives of a number of types can also wield a great deal of influence. Any state policy must operate in the general context of market rules that the Federal Energy Regulatory Commission approves and in the physical constraints of the existing power delivery system. Insufficient capacity on the power transmission system will pose a major barrier to wind development in some of the windiest areas of the country. Finally, any state or federal policy to support wind will only be as effective as the quality of the wind resource, which also bounds any new investment in wind. 


\section{ACKNOWLEDGMENTS}

This work was funded by the U.S. Department of Energy's (DOE) Office of Energy Efficiency and Renewable Energy. It was presented at the American Wind Energy Association's

Windpower Conference held May 18-21, 2003, in Austin, Texas. The authors wish to thank all of the wind energy developers, advocates, regulators, and policymakers who provided information on state-level experience that was essential to the preparation of this paper. We are also indebted to the following reviewers who provided thoughtful comments on earlier drafts: Kevin Porter of Exeter Associates, Michael Milligan of NREL, and Jim Caldwell of AWEA. Finally, we wish to thank Larry Flowers of NREL for his support of this work and Michelle Kubik of NREL for her editorial assistance. 


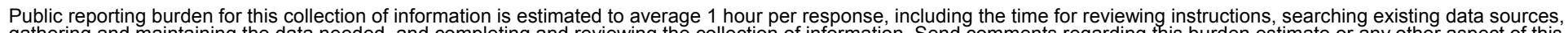

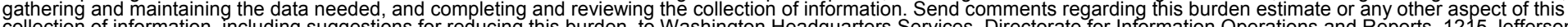

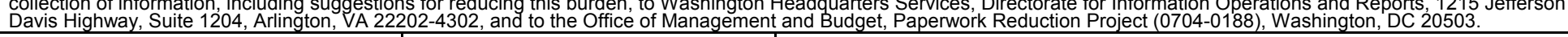

\begin{tabular}{l|l|l} 
1. AGENCY USE ONLY (Leave blank) & $\begin{array}{l}\text { 2. REPORT DATE } \\
\text { July } 2003\end{array}$ & $\begin{array}{l}\text { 3. REPORT TYPE AND DATES COVERED } \\
\text { Technical Report - Analysis }\end{array}$
\end{tabular}

4. TITLE AND SUBTITLE

Policies and Market Factors Driving Wind Power Development in the United States

5. FUNDING NUMBERS

6. AUTHOR(S)

L. Bird, B. Parsons, T. Gagliano, M. Brown, R. Wiser, M. Bolinger

TA: WER3.3010

7. PERFORMING ORGANIZATION NAME(S) AND ADDRESS(ES)

National Renewable Energy Laboratory

1617 Cole Blvd.

Golden, CO 80401-3393 8. PERFORMING ORGANIZATION
REPORT NUMBER

NREL/TP-620-34599

9. SPONSORING/MONITORING AGENCY NAME(S) AND ADDRESS(ES)

10. SPONSORING/MONITORING AGENCY REPORT NUMBER

11. SUPPLEMENTARY NOTES

12a. DISTRIBUTION/AVAILABILITY STATEMENT

National Technical Information Service

12b. DISTRIBUTION CODE

U.S. Department of Commerce

5285 Port Royal Road

Springfield, VA 22161

13. ABSTRACT (Maximum 200 words)

In the United States, there has been substantial recent growth in wind energy generating capacity, with growth averaging $24 \%$ annually during the past five years. With this growth, an increasing number of states are experiencing investment in wind energy. Wind installations currently exist in about half of all U.S. states. This paper explores the policies and market factors that have been driving utility-scale wind energy development in the United States, particularly in the states that have achieved a substantial amount of wind energy investment in recent years. Although there are federal policies and overarching market issues that are encouraging investment nationally, much of the recent activity has resulted from state-level policies or localized market drivers. In this paper, we identify the key policies, incentives, regulations, and markets affecting development, and draw lessons from the experience of leading states that may be transferable to other states or regions. We provide detailed discussions of the drivers for wind development in a dozen leading states-California, Colorado, lowa, Kansas, Minnesota, New York, Oregon, Pennsylvania, Texas, Washington, West Virginia, and Wyoming.

14. SUBJECT TERMS
analysis; wind energy; wind capacity; system benefits funds; integrated resource planning; green power markets; property-tax incentives; sales-tax incentives; state-level drivers; AWEA; American Wind Energy Association; California; Colorado; lowa; Kansas; Minnesota; New York; Oregon; Pennsylvania; Texas; Washington; West Virginia; Wyoming; Lori Bird; Brian Parsons; Troy Gagliano; Matthew Brown; Ryan Wiser; Mark Bolinger

\begin{tabular}{|c|c|c|c|c|}
\hline 17. & $\begin{array}{l}\text { SECURITY CLASSIFICATION } \\
\text { OF REPORT } \\
\text { Unclassified }\end{array}$ & $\begin{array}{l}\text { 18. SECURITY CLASSIFICATION } \\
\text { OF THIS PAGE } \\
\text { Unclassified }\end{array}$ & $\begin{array}{l}\text { 19. SECURITY CLASSIFICATION } \\
\text { OF ABSTRACT } \\
\text { Unclassified }\end{array}$ & $\begin{array}{l}\text { 20. LIMITATION OF ABSTRACT } \\
\text { UL }\end{array}$ \\
\hline
\end{tabular}

